\title{
Moringa Oleifera Leaf Extract Repairs the Oxidative Misbalance following Sub-Chronic Exposure to Sodium Fluoride in Nile Tilapia Oreochromis niloticus
}

\author{
Nirmen F. Ahmed ${ }^{1}$, Kadry M. Sadek ${ }^{1}$, Magdy Kh. Soliman ${ }^{2}$, Reyad H. Khalil ${ }^{3}$, \\ Asmaa F. Khafaga ${ }^{4, * \mathbb{D}}$, Jamaan S. Ajarem ${ }^{5}$, Saleh N. Maodaa ${ }^{5}$ and Ahmed A. Allam ${ }^{6}$ \\ 1 Department of Biochemistry, Faculty of Veterinary Medicine, Damanhour University, \\ Damanhour 22511, Egypt; Nirmenfathi@gmail.com (N.F.A.); ksaadek@gmail.com (K.M.S.) \\ 2 Department of Poultry and Fish diseases, Faculty of Veterinary Medicine, Damanhour University, \\ Damanhour 22511, Egypt; m.khalil@gmail.com \\ 3 Department of Poultry and Fish diseases, Faculty of Veterinary Medicine, Alexandria University, \\ Edfina 22758, Egypt; Riad.Khalil@alexu.edu.eg \\ 4 Department of Pathology, Faculty of Veterinary Medicine, Alexandria University, Edfina 22758, Egypt \\ 5 Department of Zoology, College of Science, King Saud University, Riyadh 11451, Saudi Arabia; \\ jajarem@ksu.edu.sa (J.S.A.); maodaa_28@yahoo.com (S.N.M.) \\ 6 Department of Zoology, Faculty of Science, Beni-suef University, Beni-suef 65211, Egypt; \\ Allam1081981@yahoo.com \\ * Correspondence: Asmaa.Khafaga@alexu.edu.eg
}

Received: 28 February 2020; Accepted: 31 March 2020; Published: 5 April 2020

Simple Summary: The present study investigated the antioxidant effect of ethanolic extract of Moringa Oleifera (MO) leaves against sodium fluoride-induced toxicity in Nile tilapia. It is concluded that MO leaves are a promising antioxidant plant via downregulation of lipid peroxidation, and upregulation of antioxidant enzyme activity including SOD, CAT, GPx, GSH, and TAC in liver, kidney, gills, and muscle tissue in a time-dependent manner, in addition to downregulation of mRNA expression of antioxidant-related genes.

\begin{abstract}
The potential antioxidant property of Moringa oleifera (MO) has been the recent focus of an increased number of studies. However few studies investigated its antioxidative ability against sodium fluoride-induced redox balance breakdown in Oreochromis niloticus. Thus, this study evaluates the effects of $\mathrm{MO}$ against the oxidative stress induced by sub-chronic exposure to sodium fluoride (NaF). A total of 264 fish ( $40 \pm 3 \mathrm{~g} \mathrm{BW}$ ) were used to calculate the $96 \mathrm{hr}-\mathrm{LC} 50$ of NaF and perform the sub-chronic exposure study. $96 \mathrm{hr}-\mathrm{LC} 50$ of NaF was calculated as $(61 \mathrm{mg} / \mathrm{L})$. The 1/10 dose of the calculated $96 \mathrm{hr}-\mathrm{LC} 50(6.1 \mathrm{mg} / \mathrm{L})$ was used to complete the sub chronic exposure for eight weeks. Fish were divided into four groups ( $\mathrm{n}=51$; three replicates each); control, non-treated group; $\mathrm{NaF}$ group (exposed to $\mathrm{NaF} 6.1 \mathrm{mg} / \mathrm{L}$ ); $\mathrm{MO}$ group (treated with $1 \% \mathrm{MO}$ of diet); and $\mathrm{NaF}+\mathrm{MO}$ (exposed to $\mathrm{NaF} 6.1 \mathrm{mg} / \mathrm{L}$ and treated with $1 \% \mathrm{MO}$ of diet). The results revealed that the sub-chronic exposure to $\mathrm{NaF}(6.1 \mathrm{mg} / \mathrm{L})$ was substantially increased malondialdehyde (MDA) and decrease the activities of superoxide dismutase (SOD), catalase (CAT), glutathione reduced (GSH), glutathione peroxidase (GPx), and total antioxidant capacity (TAC) in the gills, liver, kidney, and muscle tissue in a time-dependent manner. In addition, a significant reduction in mRNA expression of GST in the liver was reported following $\mathrm{NaF}$ exposure. On the contrary, dietary supplementation of $\mathrm{MO}$ to NaF-exposed fish resulted in a significant reduction in MDA levels, and a significant elevation of SOD, CAT, GSH, GPx, and TAC activities in a time-dependent manner, in addition to significant elevation of GST mRNA expression in liver tissue. It could be concluded that a $1 \% \mathrm{MO}(w / w)$ ration is a promising antioxidant plant that may successfully use to interfere with the oxidation processes induced by $\mathrm{NaF}$ in various tissues of Oreochromis niloticus.
\end{abstract}


Keywords: Moringa ethanolic extract; NaF; Nile tilapia; malondialdehyde; antioxidants; GST mRNA expressions

\section{Introduction}

Fluoride is a nonmetallic negatively-charged ion. It occurs naturally in the rocks, soil, and water of seas, rivers, and lakes [1]. The concentrations of fluoride in polluted seawaters generally range from 1.2 to $1.5 \mathrm{mg} \mathrm{F} / \mathrm{L}$ [2]. The dramatic increases in industrial waste, municipal sewage, and the use of sodium fluoride-based insecticides can result in an increase of fluoride concentration in aquatic media which, in turn, leads to fluoride toxicity and accumulation in fish tissues [3,4]. These increases in fluoride toxicity in fish are positively correlated with the increasing concentration of aquatic medium fluoride, water temperature, and exposure time [4]. Interestingly, elevated concentrations of fluoride were reported to delay the hatching of fertilized eggs of freshwater fish [5], inhibit fish growth, such as length and weight [6], and accumulated in fish bone, gill, cartilage, and skin [7]. These findings may suggest the economic and medicinal needs to find suitable herbal remedy to reduce these adverse effects of fluoride on fish. The exposure to high concentrations of fluoride could trigger the adverse toxic impact on different biological processes [8]. In different words, low concentration of fluoride $(\mu \mathrm{M})$ might act as a promoter for cell proliferation and enzymatic activity; however, a high concentration of fluoride $(\mathrm{mM})$ could act as an enzymatic inhibitor. This enzyme inhibitory action occurred due to the strong electronegativity of fluoride, where it forms ions and interacts with enzymes leading to toxicity and biological damage to different body systems [9], such as the central nervous system [10], spleen and immune organs [11], the male reproductive system [12], and the liver [13,14].

Few previous studies concluded the role of fluoride as a toxic, cumulative, environmental pollutant in aquatic life [8] where they are regularly exposed to elevated concentrations of fluoride in surface waters. The adverse impact of fluoride was ensured when it enters the food chain and accumulates in different tissues of aquatic organisms, particularly fish bone and the invertebrate's exoskeleton. In addition, it can disturb the normal metabolic homeostasis and exert its adverse effect even at very low levels. Recent evidence in fish models indicated that high concentrations of fluoride can modify growth and development, induced pathologic bone deformity, and disrupt cell respiration and metabolism [15-17]. These events lead to an excessive production of reactive oxygen species (ROS) with resultant impairment of antioxidant system, DNA damage, mitochondrial dysfunction, and increased mortality rate [18,19].

Moringa oleifera (MO) is an edible tree, belonging to the Moringaceae family. It is present in tropical and subtropical areas of Asia and Africa. MO is known for its nutritional and pharmacological importance [20-22]. All over the world, MO has been extensively and traditionally used to alleviate several afflictions, such as hepatorenal, cardiovascular, hematological, and gastrointestinal disorders. In addition, it has efficient anti-inflammatory, antimicrobial, and anti-oxidative properties [22-24]. Natural herbalists use the different parts of $\mathrm{MO}$, such as leaves, roots, flowers, fruit, and seeds, to obtain different extracts of Moringa. Among them, Moringa leaf extract is known for its rich contents of calcium, potassium, iron, phosphorous, and vitamins (vitamins A, D, C, E, ascorbic acid, and $\beta$-carotene), in addition to natural antioxidants and phytochemical flavonoids, such as polyphenol oxidase, oxidase, and catalase, which has great medicinal importance [20,25-27]. Recent studies focused on the use of MO leaf meal in fish feeds as a cheap and locally available plant, with increasing protein contents [28].

Nile tilapia, Oreochromis niloticus, is a type of freshwater fish that is commonly used in toxicological investigations [29]. It is characterized by resistance to diseases, fast growth, and easy adaption to commercial diets [30]. Several studies were performed to evaluate the importance of medicinal plants' leaf extracts for detoxification of polluted ecosystems [31-35], promote fish growth [36], and improve resistance against toxicity. However, in one recent study which has evaluated the ameliorative effect of $\mathrm{MO}$ leaf extract against sodium fluoride $(\mathrm{NaF})$ in sea bream via the estimation of liver function, 
catalase, and superoxide dismutase activity [37], the authors concluded an efficient hepatoprotective and antioxidant effect of MO leaf extract. However, more investigation is needed to explain the anti-oxidative efficacy of $\mathrm{MO}$ ethanolic extract against $\mathrm{NaF}$ toxicity in aquatic organisms. Hence, the present investigation was conducted to assess the antioxidant and antigenotoxic ability of MO against NaF-induced oxidative stress via evaluation of oxidative stress biomarkers (malondialdehyde (MDA), superoxide dismutase (SOD), catalase (CAT), glutathione peroxidase (GPx), glutathione reduced (GSH), and total antioxidant capacity (TAC)) in various tissues (liver, kidney, gills, and muscle), and via the molecular evaluation of the antioxidant related gene (glutathione $S$ transferase (GST) in the liver of Nile tilapia as a fish model.

\section{Materials and Methods}

All procedures by this study were in accordance with international ethical standards. The research involved no human participants.

\subsection{Chemicals}

Sodium fluoride (NaF; $\geq 99 \%$; MW 41.99; EC No. 231-667-8) was purchased from Sigma-Aldrich (Hamburg, Germany). Kits for malondialdehyde (Cat\# MD 2529), Superoxide dismutase (Cat\# SD 2521), catalase (Cat\# CA2517), glutathione peroxidase (Cat\# GP 2524), glutathione reduced (Cat\# GR 2511), and total antioxidant capacity (Cat\# TA 25 13) were obtained from Biodiagnostic Co., Cairo, Egypt. All chemicals were of the highest available analytical grades.

\subsection{Preparation of MO Leaf Ethanolic Extract}

The fresh leaves of the MO plant were obtained by personal communication from El-Sharkia Governorate, Egypt. The collected leaves were purified, washed with distilled water, and dried in a shed for two weeks, until they become crispy in touch while retaining their greenish coloration. Later, ethanolic extract of $\mathrm{MO}$ leaves was prepared according to the previously described method [38]. Briefly, $1000 \mathrm{~g}$ were macerated in absolute ethyl alcohol and distilled water (ethanol $80 \%$ ) and left for $48 \mathrm{~h}$. The resulting extract was filtered through muslin cloth on a plug of glass wool in a glass column, concentrated, and evaporated via a rotary evaporator at $45^{\circ} \mathrm{C}$ to dryness to prevent the active ingredients' denaturation. Following that, the extract was diluted to $1000 \mathrm{~mL}$ (polysaccharide was used as a carrier) and stored in a refrigerator.

\subsection{Gas Chromatography-Mass Spectrometry(GC-MS) Analysis}

A trace GC Ultra-ISQ mass spectrometer with a direct capillary column TG-5MS (30 m $\times 0.25 \mathrm{~mm}$ $\times 0.25 \mu \mathrm{m}$ ) was injected by $10 \mu \mathrm{L}$ of $\mathrm{MO}$ ethanolic extract. The column oven temperature was started at $60^{\circ} \mathrm{C}$ and then increased by $5^{\circ} \mathrm{C} / \mathrm{min}$ until reaching $280^{\circ} \mathrm{C}$. The injector and detector (MS transfer line) temperatures were kept at $250^{\circ} \mathrm{C}$. A helium flow rate of $1 \mathrm{~mL} / \mathrm{min}$. was used as the carrier gas for $37.83 \mathrm{~min}$. The solvent delay was $2 \mathrm{~min}$. and diluted samples of $1 \mu \mathrm{L}$ were injected automatically using auto-sampler AS3000 coupled with GC in the splitless mode. The ion source and quadrupole temperatures were set at 200 and $150{ }^{\circ} \mathrm{C}$, respectively. The mass spectra of the identified components were determined by comparison to NIST 11 mass spectral database (Figure 1).

\subsection{Fish Maintenance}

A total of 264 apparently healthy and uniform size and weight $O$. niloticus (with average body weight $40 \pm 3 \mathrm{~g}$ ) were obtained from the Central Laboratory of Abbassia Fish Farm, Egypt. Fish were acclimated for 14 days in full glass aquaria measuring $(40 \times 30 \times 40 \mathrm{~cm})$ and maintained under standard laboratory condition (oxygen saturation 90-95\%, $\mathrm{pH} 6.5$, water temperature of $25 \pm 2{ }^{\circ} \mathrm{C}$, total hardness $150 \mathrm{mg} / \mathrm{L}$, and 12:12 dark/light cycle). Fish were fed on a commercial fish pellet diet 
containing $25 \%$ crude protein. The diet was provided daily at a fixed feeding ratio of $3 \%$ of the body weight of the fish [39].

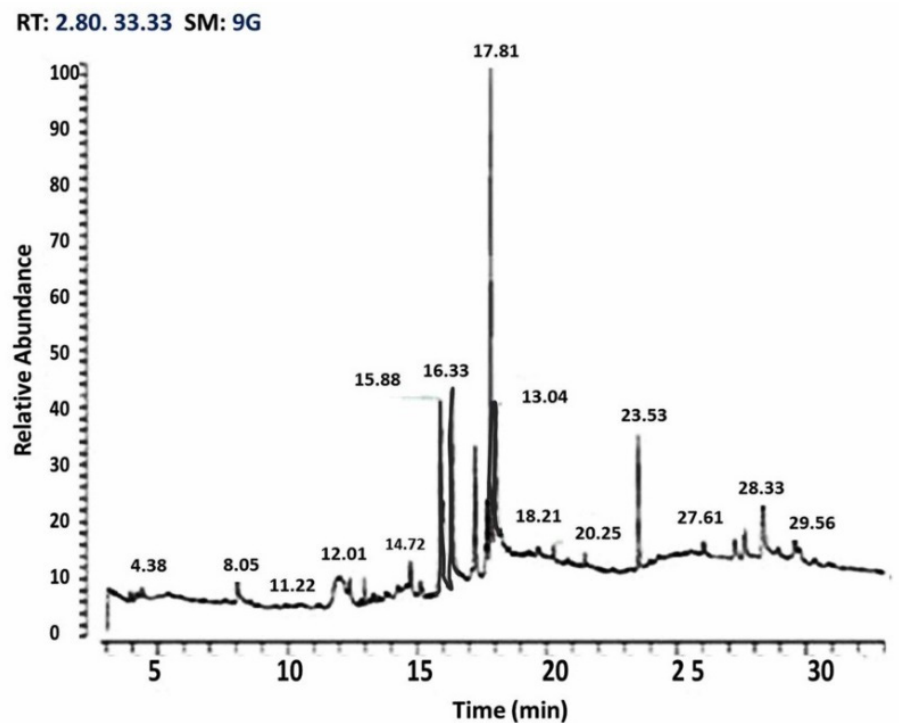

Figure 1. The mass spectra of the identified components of MO as compared to NIST 11 mass spectral database.

\subsection{Determination of $96-h$ LC50 of Sodium Fluoride}

After acclimation period, a total number of 60 apparently health fish were selected and allocated into six equal groups ( $\mathrm{n}=10$ in two replicates; each replicate contains five fish). Fish were consistently exposed to $0,20,40,60,80$, and $100 \mathrm{mg} / \mathrm{L}$ of NaF. The behavioral, clinical, and post-mortem changes were closely followed up and recorded during the experiment. Mortalities were checked every $24 \mathrm{~h}$ and the dead fish were immediately removed. The 96-h LC50 of sodium fluoride was determined and calculating according to Behrens and Karber [40].

\subsection{Experimental Design}

Fish were randomly divided into four equal groups (51 fish per each). Each group consisted of three replicates (17 each). The 1st group served as control non-treated group. The 2nd group supplemented with MO leaf extract (1\% (w/w) ration). The 3rd group exposed to NaF (1/10 LC50; $6.1 \mathrm{mg} / \mathrm{L})$ according to Singh et al. [41]. The 4th group exposed to NaF $(6.1 \mathrm{mg} / \mathrm{L})$ and supplemented with $\mathrm{MO}(1 \%)$ in ration $(w / w)$. The experimental period was extended up to eight weeks, where samples were collected every two weeks from all aquaria for analyses. During the experimental period, the water of the aquaria changed daily with clean aerated water contains the same concentrations of $\mathrm{NaF}$. Fish were kept in static fiberglass tanks with side channel blowers to blow the air that was diffused into each tank with an air stone. The tested pellet diet was prepared by mixing the commercial fish diet with $1 \%(w / w)$ MO leaf extract powder and a little water, then the mixture was run through a pasta maker and the pellets placed onto a cookie sheet. Following that, pellets were dried on low heat in an oven. The diet was administrated to fish twice daily at 08:00 and 13:00.

\subsection{Sample Collection and Preparation}

At the 2nd, 4th, 6th, and 8th weeks of the experiment, twelve fish were collected from each treated group ( 4 fish/replicate), fish were anaesthetized with $0.02 \%$ benzocaine solution and tissue samples were collected from the gills, liver, kidney, and muscle and stored at $-20{ }^{\circ} \mathrm{C}$ for further evaluation of oxidant/antioxidant parameters. Stored tissue samples (gills, liver, kidney, and muscle) were washed in an ice cold $1.15 \% \mathrm{KCl}$ solution, blotted, weighed, and homogenized with $0.1 \mathrm{M}$ phosphate buffer 
(pH 7.2). Later, tissues were put in a mortar and blended with acid-washed laboratory sand with a pestle. The resulting homogenate was centrifuged at $2500 \mathrm{rpm}$ for $15 \mathrm{~min}$. The supernatant was decanted and stored at $-20^{\circ} \mathrm{C}$.

\subsection{Estimation of Antioxidative/Antioxidative Parameters in Tissues Homogenate}

The stored samples of tissue homogenate were used for spectrophotometric determination of antioxidant enzymes activity using a UV-VIS spectrophotometer. Malondialdehyde (MDA) levels were estimated in tissues homogenate samples using commercially available colorimetric kits. The assay relied on the reaction between MDA and thiobarbituric acid at absorbance of $532 \mathrm{~nm}$ to form a pink-colored complex [42]. Superoxide dismutase (SOD, EC 1.15.1.1) activity was colorimetrically evaluated using laboratory-supplied kits; the assay based on the inhibition of nitroblue tetrazolium dye reduction through phenazine methosulphate enzyme [43]. CAT activity (CAT, EC 1.11.1.6) was estimated using commercially supplied kits by interaction with $\mathrm{H}_{2} \mathrm{O}_{2}$, and then inhibition of this reaction by CAT inhibitor [44]. In addition, activity of glutathione peroxidase (GPx, EC 1.11.1.9) was estimated according to Paglia and Valentine [45] using commercially available kits. Furthermore, levels of glutathione reduced (GSH) was colorimetrically evaluated using laboratory provided kits, the principle of assay based on the measuring the conjugation of 1-chloro-2,4-dinitrobenzene with reduced glutathione at an absorbance of $340 \mathrm{~nm}$ [46]. The total antioxidant capacity (TAC) was spectrophotometrically estimated in tissue homogenate samples using laboratory-supplied kits according to the manufacturer's instructions.

\subsection{Evaluations of RT-PCR $m R N A$ Expressions of Glutathione S Transferase Genes}

At the end of the experiment, liver samples were collected from different groups to perform the real-time reverse transcription polymerase chain reaction (RT-PCR) analysis of mRNA expression of the antioxidant related gene (glutathione $S$ transferase; GST). The total mRNA was extracted from six liver samples/group using mRNA extraction kit (QIAamp ${ }^{\circledR}$ RNeasy Mini kit; QIAGEN GmbH, Hilden, Germany) according to the manufacturer's instructions. One hundred milligrams of each live sample was added to $600 \mu \mathrm{L}$ of RLT buffer (containing $10 \mu \mathrm{L} \beta$-mercaptoethanol $/ \mathrm{mL}$ ). Samples were homogenized by placing the tube into the adaptor sets fixed into the clamps of a Qiagen tissue lyser. Digestion of DNase was applied for $15 \mathrm{~min}$ at $30{ }^{\circ} \mathrm{C}$ to obtain highly pure RNA and remove any DNA residue. The quality of the extracted RNA was confirmed using $2 \%$ agarose electrophoresis according to the manufacturer's instruction. Real-time RT-PCR was performed via use the QuantiTect SYBR Green PCR Master Mix (Qiagen, Germany, GmbH). A 25- $\mu$ L reaction of GST gene was prepared by $12.5 \mu \mathrm{L}$ of $2 \times$ QuantiTect SYBR Green PCR Master Mix (QIAGEN GmbH, Hilden, Germany), $0.25 \mu \mathrm{L}$ of RevertAid Reverse Transcriptase $(200 \mathrm{U} / \mu \mathrm{L})$ (Thermo Fisher scientific, Milano, Italy), $0.5 \mu \mathrm{L}$ of primer at an amount of $20 \mathrm{pmol}, 8.25 \mu \mathrm{L}$ of water, and $3 \mu \mathrm{L}$ of RNA template. The primer sequences for the target genes are described in Table 1. Stratagene MX3005P real-time PCR machine was used to perform the reaction. Amplification curves and threshold cycle $(\mathrm{Ct})$ values were determined using Stratagene MX3005P software. The Ct value of each sample was compared with the positive control samples to estimate variations in mRNA expression among the different samples according to the 2- $\Delta \Delta \mathrm{Ct}$ method described by Yuan et al. [47].

Table 1. Primer sequences used for RT-PCR.

\begin{tabular}{crc}
\hline Gene Name & Forward Primer & Reverse Primer \\
\hline$\beta$-actin ${ }^{*}$ & CCTCACCCTCAAGTACCCCAT & TTGGCCTTTGGGTTGAGTG \\
GST & ATGATCTATGGCAACTATGAGACAGG & GAAGTACAAACAGATTGTATCCGC \\
\hline \multicolumn{2}{c}{${ }^{*}$ Housekeeping gene. }
\end{tabular}




\subsection{Statistical Analysis}

The collected data were analyzed statistically with general linear model (GLM) using $4 \times 4$ factorial design according to the following model: Xifk $=\mu+\mathrm{Ti}+\mathrm{Pf}+\mathrm{Ti} \times \mathrm{Pf}+$ Eifk, where: Xifk $=$ the value of any observation, $\mu=$ the population mean $\mathrm{Ti}=$ treatment effect $(\mathrm{i}=\operatorname{control}(\mathrm{CTR})-$ sodium fluoride $(\mathrm{NaF})-$ Moringa oleifera $(\mathrm{MO})-\mathrm{NaF}+\mathrm{MO}), \mathrm{Pf}=$ Time effect $(\mathrm{f}=2,4,6$, and 8 weeks), $\mathrm{Ti} \times$ $\mathrm{Pf}=$ the interaction between the treatment and the time effect, and Eifk = random error. Levene's test was firstly conducted to assess the normality of data. Differences among means considered significant at level $(p<0.05)$. Data were also tested for normality using the Kolmogorov-Smirnov test and considered normally distributed at $p>0.05(p=0.11)$. SPSS statistical package version 17.0 for Windows (IBM, Armonk, NY, USA) was used for all data analysis.

\section{Results}

\subsection{The Chemical Composition of $M O$}

As illustrated in Table 2 and Figure 1, GC-MS analysis of MO revealed that the major phytoconstituents present in Moringa oleifera leaves ethanolic extract are: eugenol $(45.23 \%)$, caryophyllene $(11.35 \%)$, hexadecanoic acid $(7.23 \%)$, phenol $(6.14 \%)$, octadecenoc acid $(3.29 \%)$, heptadecyne $(3.18 \%)$, cyclopropanoctonic $(4.17 \%)$, heptatriacotanole $(1.26 \%)$, and quercetin $(0.89 \%)$.

Table 2. GC-MS analysis of major phytoconstituents present in Moringa oleifera leaves ethanolic extract.

\begin{tabular}{ccccc}
\hline No. & Compound Name & RT (Minutes) & Relative Abundance (\%) & Molecular Formula \\
\hline 1 & Caryophyllene & 15.88 & 11.35 & $\mathrm{C} 15 \mathrm{H} 24$ \\
2 & Eugenol & 17.81 & 45.23 & $\mathrm{C} 10 \mathrm{H} 12 \mathrm{O} 2$ \\
3 & Heptadecyne & 20.25 & 3.18 & $\mathrm{C} 17 \mathrm{H} 32 \mathrm{O}$ \\
4 & Phenol & 27.61 & 6.14 & $\mathrm{C} 12 \mathrm{H} 14 \mathrm{O} 3$ \\
5 & Hexadecanoic acid & 28.33 & 7.23 & $\mathrm{C} 38 \mathrm{H} 68 \mathrm{O} 8$ \\
6 & Heptatriacotanole & 28.42 & 1.26 & $\mathrm{C} 37 \mathrm{H} 76 \mathrm{O}$ \\
7 & Octadecenoic acid & 29.56 & 3.29 & $\mathrm{C} 19 \mathrm{H} 36 \mathrm{O} 2$ \\
8 & Quercetin & 31.19 & 0.89 & $\mathrm{C} 18 \mathrm{H} 16 \mathrm{O} 7$ \\
9 & Cyclopropanoctonic & 31.24 & 2.17 & $\mathrm{C} 22 \mathrm{H} 38 \mathrm{O} 2$ \\
\hline
\end{tabular}

\subsection{Determination of LC50 Sodium Fluoride (NaF) in O. niloticus}

As shown in Figure 2 and Table 3, the lethal concentration 50 (LC50) of $\mathrm{NaF}$ in O. niloticus has been calculated as $61 \mathrm{mg} / \mathrm{L}$; therefore, the $1 / 10$ dose of $\mathrm{NaF}$ LC50 was estimated as $6.1 \mathrm{mg} / \mathrm{L}$.

Table 3. Determination of sodium fluoride LC50 in O. niloticus.

\begin{tabular}{ccccc}
\hline $\begin{array}{c}\text { Sodium Fluoride } \\
\text { Dose }(\mathbf{m g} / \mathbf{L})\end{array}$ & $\begin{array}{c}\text { Overall Deaths } \\
\text { within } \mathbf{9 6} \mathbf{~ h}\end{array}$ & A & B & AB \\
\hline 0 (control) & 0 & 0 & 0 & 0 \\
20 & 0 & 20 & 0 & 0 \\
40 & 2 & 20 & 1.0 & 20 \\
60 & 5 & 20 & 3.5 & 70 \\
80 & 7 & 20 & 6.0 & 120 \\
100 & 10 & 8.5 & $\sum \mathrm{A} \times \mathrm{B}=390$ \\
\hline
\end{tabular}

$\mathrm{A}=$ differences between the two consecutive doses, $\mathrm{B}=$ arithmetic mean of the mortality caused by two consecutive doses. $96 \mathrm{~h} \mathrm{LC50}=\mathrm{LC} 100-\sum(\mathrm{A} \times \mathrm{B}) / \mathrm{N}=100-390 / 10=61.0 \mathrm{ppm}$. or $(\mathrm{mg} / \mathrm{L})$. Lethal concentration 50 (LC50) of sodium fluoride in $O$. niloticus $=61 \mathrm{mg} / \mathrm{L}$. A $1 / 10$ dose of the LC50 of Sodium fluoride in O. niloticus to induce chronic toxicity was $=6.1 \mathrm{mg} / \mathrm{L}$. 


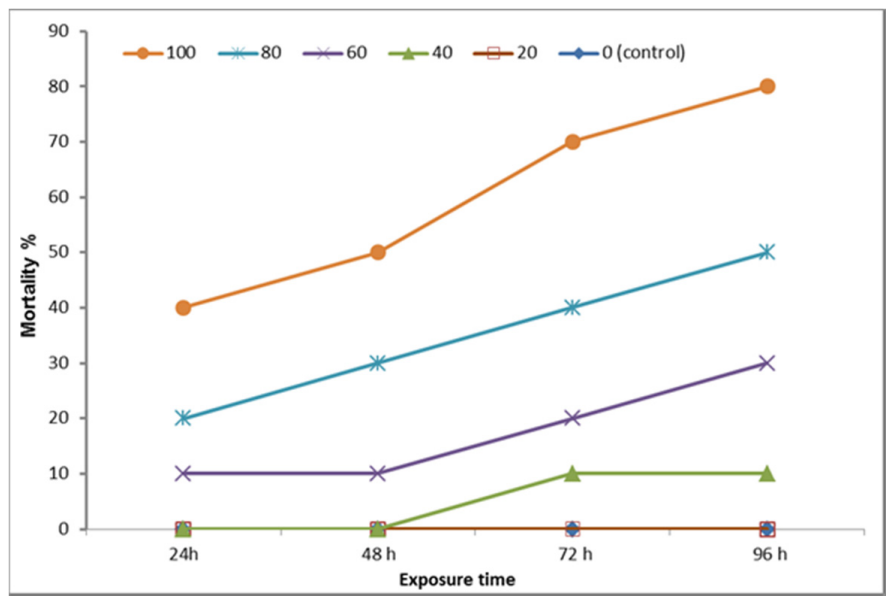

Figure 2. Mortality percentage of fish exposed to different concentration of $\mathrm{NaF}(20,40,60,80$, and $100 \mathrm{mg} / \mathrm{L})$ at different time points $(24,48,72$, and $96 \mathrm{~h})$. The total number of fish/group $=10$ fish.

\subsection{Effect of $\mathrm{NaF}$ and/or MO on Malondialdehyde Levels (MDA) in Tissues Homogenate}

As shown in Table 4, the levels of MDA in gills tissues showed significant elevation in NaF and $\mathrm{NaF}+\mathrm{MO}$ exposed fish from the 4th until the 8th week of the experiment compared to their control counterparts. However, MO treated fish showed significant reduction in MDA levels from the 4 th until the 8th week of experiment compared to the other groups. This significant up-regulation was time-dependent where it increased significantly with the increment of exposure period. The same trend of MDA level in gills tissues were reported for the liver, kidney, and muscles. MDA significantly increased in $\mathrm{NaF}$ and $\mathrm{NaF}+\mathrm{MO}$ groups but significantly decreased in the $\mathrm{MO}$ group compared to the control fish, with a time-dependent significant increment.

Table 4. Effect of Sodium fluoride (NaF) and/or M. Oleifera (MO) on malondialdehyde (MDA) (U/g tissue) in tissue homogenates of $O$. niloticus gills, liver, kidney, and muscle.

\begin{tabular}{|c|c|c|c|c|c|}
\hline \multirow{2}{*}{ Groups } & \multicolumn{4}{|c|}{ Period of Exposure } & \multirow{2}{*}{$p$-value } \\
\hline & 2nd Week & 4th Week & 6th Week & 8th Week & \\
\hline \multicolumn{6}{|c|}{ Gills } \\
\hline CTR & $8.66+0.70^{\mathrm{A} \mathrm{a}}$ & $8.50+0.19 \mathrm{~A} \mathrm{~b}$ & $8.66+0.44^{\mathrm{Ac}}$ & $8.38+0.42 \mathrm{Ab}$ & 0.433 \\
\hline $\mathrm{NaF}$ & $10.02+0.68^{\mathrm{Da}}$ & $12.20+0.67 \mathrm{Ca}$ & $15.38+0.65^{\text {В а }}$ & $18.59+0.62 \mathrm{~A} \mathrm{a}$ & 0.025 \\
\hline $\mathrm{NaF}+\mathrm{MO}$ & $9.95+0.22 \mathrm{Ca}$ & $11.32+0.30 \mathrm{Ca}$ & $13.07+0.33^{\mathrm{B} \mathrm{b}}$ & $17.34+0.79 \mathrm{~A} \mathrm{a}$ & 0.038 \\
\hline MO & $8.77+0.28^{\mathrm{A} \mathrm{a}}$ & $8.02+0.17 \mathrm{~A}, \mathrm{~B} b$ & $7.55+0.17^{\mathrm{A}, \mathrm{B} c}$ & $6.78+0.37^{\mathrm{B} \mathrm{b}}$ & 0.047 \\
\hline$p$ value & & & \\
\hline CTR & $11.68+0.73^{\mathrm{Ab}}$ & $11.67+0.54 \mathrm{Ab}$ & $10.78+0.42 \mathrm{Ac}$ & $11.54+0.67 \mathrm{Ac}$ & 0.970 \\
\hline $\mathrm{NaF}$ & $14.00+0.34 \mathrm{D} \mathrm{a}$ & $17.88+0.34 \mathrm{Ca}$ & $26.65+0.80^{\text {В а }}$ & $38.30+0.67 \mathrm{~A} \mathrm{a}$ & 0.001 \\
\hline $\mathrm{NaF}+\mathrm{MO}$ & $13.02+0.36^{\mathrm{Da}, \mathrm{b}}$ & $16.25+0.07^{\mathrm{Ca}}$ & $23.52+0.15^{\text {В b }}$ & $35.65+0.39 \mathrm{Ab}$ & 0.005 \\
\hline MO & $11.44+0.05^{\mathrm{Ab}}$ & $10.23+0.27^{\mathrm{A}, \mathrm{B} b}$ & $9.60+0.15^{\mathrm{B} \mathrm{c}}$ & $7.77+0.41 \mathrm{Cd}$ & 0.014 \\
\hline$p$ value & \multicolumn{5}{|c|}{ Kidney } \\
\hline CTR & $15.63+0.32 \mathrm{Ab}$ & $16.44+0.24 \mathrm{~A} \mathrm{~b}$ & $15.71+0.23 \mathrm{Ac}$ & $16.28+0.30 \mathrm{Ac}$ & 0.883 \\
\hline $\mathrm{NaF}$ & $16.76+0.33^{\mathrm{D} a, b}$ & $19.04+0.27^{\mathrm{Ca}}$ & $22.30+0.45^{\mathrm{B} \mathrm{a}}$ & $25.45+0.70 \mathrm{~A} \mathrm{a}$ & 0.003 \\
\hline $\mathrm{NaF}+\mathrm{MO}$ & $17.07+0.26^{\mathrm{Ca}}$ & $17.09+0.43^{\mathrm{Ca}}$ & $20.70+0.50^{\mathrm{B} \mathrm{b}}$ & $23.79+0.39 \mathrm{~A} \mathrm{~b}$ & 0.011 \\
\hline MO & $15.56+0.33^{\mathrm{Ab}}$ & $14.33+0.37^{\mathrm{A}, \mathrm{B} \mathrm{c}}$ & $13.52+0.17^{B d}$ & $11.39+0.24 \mathrm{Cd}$ & 0.023 \\
\hline$p$ value & 0.041 & $\begin{array}{l}0.001 \\
\text { Muscle }\end{array}$ & 0.001 & 0.001 & \\
\hline CTR & $27.50+0.34 \mathrm{~A} \mathrm{a}$ & $26.96+0.18 \mathrm{Ab}$ & $25.98+0.57 \mathrm{Ac}$ & $26.01+0.68 \mathrm{Ac}$ & 0.735 \\
\hline $\mathrm{NaF}$ & $28.03+0.33^{\mathrm{B} \mathrm{a}}$ & $30.26+0.31^{\mathrm{B} \mathrm{a}}$ & $32.52+0.92 \mathrm{~A} \mathrm{a}$ & $33.92+1.01 \mathrm{~A} \mathrm{a}$ & 0.021 \\
\hline $\mathrm{NaF}+\mathrm{MO}$ & $27.58+0.17 \mathrm{Ca}$ & $28.29+0.58^{\mathrm{B}, \mathrm{Cb}}$ & $29.75+0.38 \mathrm{~A}, \mathrm{~B} \mathrm{~b}$ & $30.90+0.66^{\mathrm{Ab}}$ & 0.031 \\
\hline $\mathrm{MO}$ & $26.07+0.41 \mathrm{~A} \mathrm{a}$ & $24.70+0.26^{\mathrm{A}, \mathrm{B} c}$ & $24.12+0.26^{\mathrm{A}, \mathrm{B} c}$ & $22.93+0.33^{B d}$ & 0.043 \\
\hline$p$ value & 0.212 & 0.028 & 0.006 & 0.001 & \\
\hline
\end{tabular}

Different superscript small letters within the same column indicate significantly different mean values between different groups. Different superscript capital letters within the same row indicate significantly different mean values between different periods of exposure CTR, Control; $\mathrm{NaF}$, sodium fluoride (6.1 mg/L.); $\mathrm{NaF}+\mathrm{MO}$, sodium fluoride $(6.1 \mathrm{mg} / \mathrm{L})+$ Moringa oleifera extract ( $1 \%$ in ration); $\mathrm{MO}, M$. oleifera extract ( $1 \%$ in ration). 
3.4. Effect of Sodium Fluoride and/or M. oleifera on Glutathione Reduced (GSH) Activity in Tissue Homogenate

As shown in Table 5, the levels of GSH in gills tissues showed significant reduction in $\mathrm{NaF}$ and $\mathrm{NaF}+\mathrm{MO}$ groups but GSH significantly increased from the 6th until 8th weeks of experiment, respectively, compared to the control group. This significant downregulations was time-dependent, where it decreased significantly with the increment of exposure period.

Table 5. Effect of Sodium fluoride (NaF) and/or M. Oleifera $(M O)$ on glutathione reduced (GSH) (U/g tissue) in tissue homogenates of $O$. niloticus gills, liver, kidney, and muscle.

\begin{tabular}{|c|c|c|c|c|c|}
\hline \multirow{2}{*}{ Groups } & \multicolumn{4}{|c|}{ Period of Exposure } & \multirow{2}{*}{$p$ value } \\
\hline & 2nd Week & 4th Week & 6th Week & 8th Week & \\
\hline \multicolumn{6}{|c|}{ Gills } \\
\hline CTR & $5.25+0.041^{\mathrm{Aa}}$ & $5.29+0.011 \mathrm{~A} \mathrm{a,b}$ & $5.26+0.079 \mathrm{~A}, \mathrm{~b}$ & $5.26+0.055^{\mathrm{A}, \mathrm{b}}$ & 0.932 \\
\hline $\mathrm{NaF}$ & $5.25+0.014^{\mathrm{A} \mathrm{a}}$ & $5.17+0.011 \mathrm{~A}, \mathrm{~B} b$ & $5.09+0.011^{\mathrm{B} \mathrm{c}}$ & $4.95+0.040^{C d}$ & 0.013 \\
\hline $\mathrm{NaF}+\mathrm{MO}$ & $5.24+0.032 \mathrm{~A} \mathrm{a}$ & $5.23+1.017 \mathrm{~A} \mathrm{a,b}$ & $5.25+0.038 \mathrm{Ab}$ & $5.20+0.069 \mathrm{Ac}$ & 0.843 \\
\hline MO & $5.26+0.054^{\mathrm{B} \mathrm{a}}$ & $5.37+0.052 \mathrm{~B} \mathrm{a}$ & $5.56+0.005^{\mathrm{B} \mathrm{a}}$ & $5.73+0.031 \mathrm{~A} \mathrm{a}$ & 0.011 \\
\hline$p$ value & 0.748 & $\begin{array}{c}0.043 \\
\text { Liver }\end{array}$ & 0.017 & 0.001 & \\
\hline CTR & $6.69+0.027 \mathrm{~A} \mathrm{a}$ & $6.67+0.032 \mathrm{~A} \mathrm{~b}$ & $6.65+0.034 \mathrm{Ab}$ & $6.72+0.024 \mathrm{~A} \mathrm{~b}$ & 0.736 \\
\hline $\mathrm{NaF}$ & $6.37+0.035^{\mathrm{A} \mathrm{b}}$ & $6.19+0.011^{\mathrm{Bd}}$ & $5.86+0.043^{C d}$ & $5.46+0.046^{\mathrm{Dd}}$ & 0.037 \\
\hline $\mathrm{NaF}+\mathrm{MO}$ & $6.41+0.018^{\mathrm{Bb}}$ & $6.50+0.037 \mathrm{Ac}$ & $6.19+0.043^{C c}$ & $5.64+0.025^{\mathrm{Dc}}$ & 0.005 \\
\hline $\mathrm{MO}$ & $6.79+0.034^{\mathrm{D} \mathrm{a}}$ & $6.97+0.080^{\mathrm{Ca}}$ & $7.39+0.023^{\mathrm{B} \mathrm{a}}$ & $7.86+0.044^{\mathrm{A} \mathrm{a}}$ & 0.001 \\
\hline$p$ value & 0.032 & \multicolumn{3}{|l|}{ Kidney } & \\
\hline CTR & $2.59+0.017^{\mathrm{A} \mathrm{a}}$ & $2.49+0.028 \mathrm{Ab}$ & $2.50+0.034 \mathrm{~A} \mathrm{~b}$ & $2.55+0.035 \mathrm{~A} \mathrm{~b}$ & 0.683 \\
\hline $\mathrm{NaF}$ & $2.53+0.026^{\mathrm{A} \mathrm{a}}$ & $2.39+0.008^{B b}$ & $2.34+0.051 \mathrm{~B} \mathrm{c}$ & $2.18+0.050 \mathrm{Cd}$ & 0.037 \\
\hline $\mathrm{NaF}+\mathrm{MO}$ & $2.54+0.014^{\mathrm{A} \mathrm{a}}$ & $2.43+0.018^{\mathrm{A}, \mathrm{B} \mathrm{b}}$ & $2.41+0.006^{B ~ b, c}$ & $2.34+0.033^{\mathrm{Bc}}$ & 0.043 \\
\hline MO & $2.63+0.010^{\mathrm{Ca}}$ & $2.70+0.014^{\mathrm{B}, \mathrm{C} a}$ & $2.82+0.048^{\mathrm{A}, \mathrm{B} a}$ & $2.92+0.060 \mathrm{~A} \mathrm{a}$ & 0.048 \\
\hline$p$ value & \multicolumn{4}{|c|}{ Muscle } & \\
\hline CTR & $8.67+0.036^{\mathrm{A} \mathrm{a}}$ & $8.56+0.023^{\mathrm{Ab}}$ & $8.46+0.036^{\mathrm{B} \mathrm{b}}$ & $8.57+0.013^{\mathrm{Ab}}$ & 0.637 \\
\hline $\mathrm{NaF}$ & $8.62+0.023^{\mathrm{A} \mathrm{a}}$ & $8.48+0.015^{\text {B b }}$ & $8.40+0.021^{\mathrm{B} \mathrm{b}}$ & $8.28+0.036 \mathrm{Cd}$ & 0.003 \\
\hline $\mathrm{NaF}+\mathrm{MO}$ & $8.62+0.055^{\mathrm{A} \mathrm{a}}$ & $8.53+0.017^{\mathrm{A}, \mathrm{B} b}$ & $8.43+0.017^{B, C b}$ & $8.39+0.011 \mathrm{Cc}$ & 0.047 \\
\hline $\mathrm{MO}$ & $8.68+0.012^{\mathrm{Ca}}$ & $8.73+0.023^{\mathrm{B}, \mathrm{C} a}$ & $8.82+0.020 \mathrm{~A}, \mathrm{~B}$ a & $8.90+0.021 \mathrm{~A} \mathrm{a}$ & 0.038 \\
\hline$p$ value & 0.078 & 0.031 & 0.020 & 0.001 & \\
\hline
\end{tabular}

Levels of GSH in liver tissues showed significant downregulation in $\mathrm{NaF}$ and $\mathrm{NaF}+\mathrm{MO}$ group from the 2nd weeks of experiment and along the period of experiment compared to their control counterparts. However, fish of MO treated group showed significant elevation in GSH levels at the 4th week of the experiment compared to control and other treated groups. This significant downregulation was time-dependent, where it decreased significantly with the increment of exposure period. Concerning the levels of GSH in kidney and muscles tissues, significant reduction was reported in $\mathrm{NaF}$ and $\mathrm{NaF}+\mathrm{MO}$ group from the 4th until the 8th week of experiment, respectively, and along the period of experiment compared to their control counterparts. However, fish treated with MO showed significant elevation in GSH levels for the same period of experiment compared to the control and other treated groups. This significant downregulation was time-dependent, where it decreased significantly with the increment of exposure period.

\subsection{Effect of NaF and/or MO on Glutathione Peroxidase Activities (GPx) in Tissues Homogenate}

As illustrated in Table 6, the levels of GPx in gills tissues revealed non- significant difference in $\mathrm{NaF}$ and $\mathrm{NaF}+\mathrm{MO}$ groups along the experimental period compared to control counterparts. Moreover, fish treated with MO showed a non-significant elevation in GPx levels along the experimental period 
compared to control group. Concerning the exposure period, a significant difference was detected at the 8 th week only compared to the 2nd week. Levels of GPx in liver and muscle tissues showed significant downregulation in $\mathrm{NaF}$ and $\mathrm{NaF}+\mathrm{MO}$ groups from the 2 nd until the 8th weeks of experiment compared to their control counterparts. However, fish treated with MO showed non-significant elevation in GPx levels along the experimental period compared to their counterparts in NaF group. This significant downregulation was time-dependent, where it decreased significantly with the increment of exposure period. Concerning the levels of GPx in kidney tissues, MO showed significant elevation in GPx levels from the 4 th until the 8 th weeks of the experiment compared to other group. Concerning the exposure period, significant difference was detected at the 8th week only in NaF-exposed fish compared to their counterparts at the 2 nd week.

Table 6. Effect of sodium fluoride (NaF) and/or M. Oleifera $(M O)$ on glutathione peroxidase (GPx) (U/g tissue) in tissue homogenates of $O$. niloticus gills, liver, kidney, and muscle.

\begin{tabular}{|c|c|c|c|c|c|}
\hline \multirow{2}{*}{ Groups } & \multicolumn{4}{|c|}{ Period of Exposure } & \multirow{2}{*}{$p$ value } \\
\hline & 2nd Week & 4th Week & 6th Week & 8th Week & \\
\hline \multicolumn{6}{|c|}{ Gills } \\
\hline CTR & $17.56+0.52 \mathrm{~A} \mathrm{a}$ & $17.08+0.11 \mathrm{~A} \mathrm{a}$ & $16.82+0.33^{\mathrm{A} \mathrm{a}, \mathrm{b}}$ & $16.81+0.33^{\mathrm{A} \mathrm{a}, \mathrm{b}}$ & 0.529 \\
\hline $\mathrm{NaF}$ & $17.27+0.03 \mathrm{~A} \mathrm{a}$ & $16.62+0.12$ A.B a & $16.40+0.06$ А.B b & $16.27+0.02 \mathrm{~B} \mathrm{~b}$ & 0.037 \\
\hline $\mathrm{NaF}+\mathrm{MO}$ & $17.43+0.06^{\mathrm{A} \mathrm{a}}$ & $16.74+0.11 \mathrm{~A}, \mathrm{~B}$ a & $16.52+0.08^{\mathrm{A}, \mathrm{B} a, b}$ & $16.41+0.05^{\mathrm{B} \mathrm{b}}$ & 0.022 \\
\hline $\mathrm{MO}$ & $17.62+0.53^{\mathrm{A} \mathrm{a}}$ & $17.68+0.51 \mathrm{~A} \mathrm{a}$ & $17.73+0.72 \mathrm{~A} \mathrm{a}$ & $18.00+0.22 \mathrm{~A} \mathrm{a}$ & 0.693 \\
\hline$p$ value & 0.079 & 0.320 & 0.033 & 0.047 & \\
\hline \multicolumn{6}{|c|}{ Liver } \\
\hline CTR & $27.77+0.37 \mathrm{~A} \mathrm{a}$ & $27.52+0.29 \mathrm{~A} \mathrm{a}$ & $27.78+0.34^{\mathrm{A} \mathrm{a}}$ & $26.84+0.22 \mathrm{~A} \mathrm{~b}$ & 0.683 \\
\hline $\mathrm{NaF}$ & $26.27+0.05^{A ~ b}$ & $24.78+0.25^{\mathrm{B} \mathrm{b}}$ & $22.45+0.34^{C b}$ & $18.913+0.74 \mathrm{Dc}$ & 0.002 \\
\hline $\mathrm{NaF}+\mathrm{MO}$ & $26.43+0.05^{\mathrm{A} \mathrm{b}}$ & $24.83+0.65^{\mathrm{B} \mathrm{b}}$ & $22.85+0.22 \mathrm{Cb}$ & $19.49+0.19^{\mathrm{Dc}}$ & 0.001 \\
\hline $\mathrm{MO}$ & $27.87+0.39 \mathrm{~B} \mathrm{a}$ & $28.62+0.04 \mathrm{~A}, \mathrm{~B}$ a & $28.89+0.05 \mathrm{~A}, \mathrm{~B}$ a & $29.21+0.02 \mathrm{~A} \mathrm{a}$ & 0.036 \\
\hline$p$ value & 0.019 & 0.022 & 0.014 & 0.009 & \\
\hline \multicolumn{6}{|c|}{ Kidney } \\
\hline CTR & $22.97+0.37 \mathrm{~A} \mathrm{a}$ & $22.06+0.16^{\mathrm{Bb}}$ & $22.38+0.47^{\mathrm{A}, \mathrm{b}}$ & $22.89+0.25^{\mathrm{A} \mathrm{b}}$ & 0.660 \\
\hline $\mathrm{NaF}$ & $22.28+0.12 \mathrm{~A} \mathrm{a}$ & $21.71+0.20 \mathrm{~A}, \mathrm{~B} b$ & $21.65+0.05 \mathrm{~A}, \mathrm{~B} b$ & $21.28+0.07 \mathrm{~B} \mathrm{~b}$ & 0.048 \\
\hline $\mathrm{NaF}+\mathrm{MO}$ & $22.36+0.11 \mathrm{~A} \mathrm{a}$ & $21.81+0.23^{\mathrm{Ab}}$ & $21.84+0.04 \mathrm{~A} \mathrm{~b}$ & $21.66+0.06 \mathrm{~A} \mathrm{~b}$ & 0.584 \\
\hline $\mathrm{MO}$ & $23.04+0.36 \mathrm{~A} \mathrm{a}$ & $23.20+0.29 \mathrm{~A} \mathrm{a}$ & $23.52+0.32 \mathrm{~A} \mathrm{a}$ & $23.59+0.33 \mathrm{~A} \mathrm{a}$ & 0.408 \\
\hline$p$ value & 0.849 & 0.039 & 0.022 & 0.019 & \\
\hline \multicolumn{6}{|c|}{ Muscle } \\
\hline CTR & $15.39+0.09 \mathrm{~B} \mathrm{a}$ & $15.95+0.37 \mathrm{~A}, \mathrm{~B}$ a & $16.26+0.30 \mathrm{~A} \mathrm{a}$ & $15.82+0.45^{\mathrm{A}, \mathrm{B} \text { a }}$ & 0.052 \\
\hline $\mathrm{NaF}$ & $15.29+0.11 \mathrm{~A} \mathrm{a}$ & $15.19+0.01 \mathrm{~A} \mathrm{~b}$ & $15.12+0.01 \mathrm{~A} \mathrm{~b}$ & $14.87+0.15^{\mathrm{A} \mathrm{b}}$ & 0.096 \\
\hline $\mathrm{NaF}+\mathrm{MO}$ & $15.33+0.10^{\mathrm{A} \mathrm{a}}$ & $15.45+0.09 \mathrm{~A} \mathrm{a,b}$ & $15.43+0.08 \mathrm{~A} \mathrm{~b}$ & $15.00+0.11 \mathrm{Ab}$ & 0.192 \\
\hline $\mathrm{MO}$ & $15.46+0.08 \mathrm{~A} \mathrm{a}$ & $15.53+0.07 \mathrm{~A} \mathrm{a,b}$ & $15.69+0.01 \mathrm{~A} \mathrm{a}, \mathrm{b}$ & $15.88+0.01 \mathrm{~A} \mathrm{a}$ & 0.210 \\
\hline$p$ value & 0.091 & 0.051 & 0.044 & 0.039 & \\
\hline
\end{tabular}

Different superscript small letters within the same column indicate significantly different mean values between different groups. Different superscript capital letters within the same row indicate significantly different mean values between different periods of exposure. CTR, control; $\mathrm{NaF}$, sodium fluoride (6.1 $\mathrm{mg} / \mathrm{L}$.); $\mathrm{NaF}+\mathrm{MO}$, sodium fluoride $(6.1 \mathrm{mg} / \mathrm{L})+$ Moringa oleifera extract ( $1 \%$ in ration); $\mathrm{MO}$, M. oleifera extract ( $1 \%$ in ration).

Levels of GPx in muscle tissues showed significant decreased in $\mathrm{NaF}$ and $\mathrm{NaF}+\mathrm{MO}$ groups from the 6th and 8th weeks of experiment, respectively, and along the period of experiment compared to their control counterparts. However, fish treated with MO showed significant increase in GPx levels at the 8th week of the experiment compared to $\mathrm{NaF}$ and $\mathrm{NaF}+\mathrm{MO}$ groups. Concerning the exposure period, non-significant difference was detected for different groups along the experimental period.

\subsection{Effect of Sodium Fluoride and/or M. oleifera on Catalase (CAT) Activity in Tissue Homogenate of O.} niloticus Gills, Liver, Kidney, and, Muscle

As illustrated in Table 7, the levels of CAT in gills tissues was significantly increase in MO from the 2nd until the 8th week of experiment compared to other treated and control counterparts. Concerning the exposure period, significant difference was detected at the 6th and 8th weeks in $\mathrm{NaF}$ and $\mathrm{NaF}$ group compared to the 2 nd week. Levels of CAT in liver tissues showed significant downregulation 
in $\mathrm{NaF}$ and $\mathrm{NaF}+\mathrm{MO}$ groups from the 4th week of experiment and along the period of experiment compared to their control counterparts. However, fish of MO group showed significant elevation in CAT levels compared to their counterparts in $\mathrm{NaF}$ and $\mathrm{NaF}+\mathrm{MO}$ groups from 4th until the 8th weeks of the experiment. There is significant downregulation was time-dependent, where it decreased significantly with the increment of exposure period. Concerning the levels of CAT in kidney and muscles tissues, significant reduction was reported in $\mathrm{NaF}$ and $\mathrm{NaF}+\mathrm{MO}$ and $\mathrm{MO}$ groups at the 8th week of experiment compared to their control counterparts. Concerning the exposure period, no significant difference was detected in all groups of fish along the experimental period.

Table 7. Effect of Sodium fluoride (NaF) and/or M. Oleifera (MO) on catalase (CAT) (U/g tissue) in tissue homogenates of $O$. niloticus gills, liver, kidney, and muscle.

\begin{tabular}{|c|c|c|c|c|c|}
\hline \multirow{2}{*}{ Groups } & \multicolumn{4}{|c|}{ Period of Exposure } & \multirow{2}{*}{$p$ value } \\
\hline & 2nd Week & 4th Week & 6th Week & 8th Week & \\
\hline \multicolumn{6}{|c|}{ Gills } \\
\hline CTR & $7.84+0.04 \mathrm{~A} \mathrm{a}$ & $7.76+0.04^{\mathrm{A} \mathrm{b}}$ & $7.65+0.03 \mathrm{~A} \mathrm{~b}$ & $7.85+0.03 \mathrm{~A} \mathrm{~b}$ & 0.683 \\
\hline $\mathrm{NaF}$ & $7.77+0.14 \mathrm{~A} \mathrm{a}$ & $7.59+0.02 \mathrm{~A}, \mathrm{~B} b$ & $7.46+0.05^{\mathrm{B}, \mathrm{Cb}}$ & $7.27+0.04^{C d}$ & 0.019 \\
\hline $\mathrm{NaF}+\mathrm{MO}$ & $7.79+0.06^{\mathrm{A} \mathrm{a}}$ & $7.67+0.02 \mathrm{~A} \mathrm{~b}$ & $7.54+0.04^{\mathrm{Ab}}$ & $7.54+0.02 \mathrm{Ac}$ & 0.747 \\
\hline $\mathrm{MO}$ & $7.97+0.06^{\mathrm{B} \mathrm{a}}$ & $8.07+0.06^{\mathrm{B} \mathrm{a}}$ & $8.20+0.05^{\mathrm{A}, \mathrm{B} a}$ & $8.32+0.08 \mathrm{~A} \mathrm{a}$ & 0.028 \\
\hline \multicolumn{6}{|c|}{ Liver } \\
\hline CTR & $18.78+0.3^{\mathrm{B} \mathrm{a}}$ & $19.01+0.3^{\mathrm{A}, \mathrm{B} a}$ & $18.97+0.4^{\mathrm{B} \mathrm{b}}$ & $20.21+0.3^{\mathrm{A} \mathrm{a}}$ & 0.048 \\
\hline $\mathrm{NaF}$ & $18.54+0.3^{\mathrm{A} \mathrm{a}}$ & $16.70+0.2^{\mathrm{B} \mathrm{b}}$ & $14.99+0.2^{C c}$ & $13.58+0.2^{\mathrm{Db}}$ & 0.001 \\
\hline $\mathrm{NaF}+\mathrm{MO}$ & $18.69+0.3^{\mathrm{A} \mathrm{a}}$ & $17.24+0.3^{\mathrm{B} \mathrm{b}}$ & $14.66+0.3^{C c}$ & $14.28+0.04 \mathrm{Cb}$ & 0.007 \\
\hline $\mathrm{MO}$ & $18.92+0.3^{\mathrm{Ca}}$ & $19.37+0.1^{\mathrm{B}, \mathrm{C} \mathrm{a}}$ & $20.23+0.5^{\mathrm{A}, \mathrm{B} \mathrm{a}}$ & $20.71+0.5^{\mathrm{A} \mathrm{a}}$ & 0.021 \\
\hline \multicolumn{6}{|c|}{ Kidney } \\
\hline CTR & $36.34+0.6^{\mathrm{B} \mathrm{a}}$ & $36.58+0.7 \mathrm{~B} \mathrm{a}$ & $37.55+0.6^{\mathrm{A} \mathrm{a}}$ & $38.81+0.4^{\mathrm{A} \mathrm{a}}$ & 0.049 \\
\hline $\mathrm{NaF}$ & $36.29+0.6^{\mathrm{A} \mathrm{a}}$ & $36.17+0.03 \mathrm{~A} \mathrm{a}$ & $35.67+0.1 \mathrm{~A} \mathrm{~b}$ & $35.63+0.2^{\mathrm{A} \mathrm{b}}$ & 0.102 \\
\hline $\mathrm{NaF}+\mathrm{MO}$ & $36.32+0.6^{\mathrm{A} \mathrm{a}}$ & $36.32+0.05 \mathrm{~A} \mathrm{a}$ & $35.90+0.1^{\mathrm{A} \mathrm{a}, \mathrm{b}}$ & $35.81+0.08 \mathrm{Ab}$ & 0.937 \\
\hline $\mathrm{MO}$ & $36.39+0.5^{\mathrm{A} \mathrm{a}}$ & $36.57+0.5 \mathrm{~A} \mathrm{a}$ & $36.62+0.7^{\mathrm{A} \mathrm{a}, \mathrm{b}}$ & $36.54+0.3^{\mathrm{A} \mathrm{b}}$ & 0.776 \\
\hline \multicolumn{6}{|c|}{ Muscle } \\
\hline CTR & $16.96+0.8^{\mathrm{B} \mathrm{a}}$ & $17.54+0.08^{\mathrm{B} \mathrm{a}}$ & $17.46+46^{\mathrm{B} \mathrm{a}}$ & $20.12+0.9 \mathrm{~A} \mathrm{a}$ & 0.010 \\
\hline $\mathrm{NaF}$ & $16.91+0.8^{\mathrm{A} \mathrm{a}}$ & $16.64+0.3^{\mathrm{A} \mathrm{a}}$ & $16.35+0.4 \mathrm{~A} \mathrm{a}$ & $15.95+42 \mathrm{Ab}$ & 0.087 \\
\hline $\mathrm{NaF}+\mathrm{MO}$ & $16.97+0.8^{\mathrm{A} \mathrm{a}}$ & $16.87+0.2^{\mathrm{A} \mathrm{a}}$ & $16.67+0.4^{\mathrm{A} \mathrm{a}}$ & $16.06+0.3^{\mathrm{A} \mathrm{b}}$ & 0.265 \\
\hline $\mathrm{MO}$ & $17.03+0.8^{\mathrm{A} \mathrm{a}}$ & $17.24+0.8^{\mathrm{A} \mathrm{a}}$ & $17.21+0.6^{\mathrm{A} \mathrm{a}}$ & $17.29+0.8^{\mathrm{A} \mathrm{b}}$ & 0.563 \\
\hline$p$ value & 0.658 & 0.547 & 0.172 & 0.028 & \\
\hline
\end{tabular}

Different superscript small letters within the same column indicate significantly different mean values between different groups. Different superscript capital letters within the same row indicate significantly different mean values between different periods of exposure. CTR, control; $\mathrm{NaF}$, sodium fluoride (6.1 mg/L.); $\mathrm{NaF}+\mathrm{MO}$, sodium fluoride $(6.1 \mathrm{mg} / \mathrm{L})+$ Moringa oleifera extract ( $1 \%$ in ration); MO, M. oleifera extract ( $1 \%$ in ration).

\subsection{Effect of Sodium Fluoride and/or M. oleifera on Super Oxide Dismutase (SOD) Activity in Tissue Homogenate}

As illustrated in Table 8, the levels of SOD in gills tissues showed significant decrease in NaF and $\mathrm{NaF}+\mathrm{MO}$ group fish at the 4th week of experiment and along the experimental period compared to control counterparts. Moreover, fish of the $\mathrm{NaF}+\mathrm{MO}$ group showed a non-significant elevation in SOD levels along the experimental period compared to their counterparts in the NaF exposed group. Concerning the exposure period, significant difference was detected at the 6th and 8th weeks of experiment in the $\mathrm{NaF}$ and $\mathrm{NaF}+\mathrm{MO}$ groups, respectively, compared to the 2nd week. Moreover, levels of SOD in the liver, kidneys, and muscle tissues showed significant downregulation in $\mathrm{NaF}$ and $\mathrm{NaF}+\mathrm{MO}$ groups of fish from the 2nd and 4th weeks of experiment, and along the period of experiment compared to their control counterparts. However, fish of the $\mathrm{NaF}+\mathrm{MO}$ group showed a non-significant elevation in SOD levels along the experimental period compared to their counterparts 
in the NaF-exposed group. This significant downregulation was time-dependent, where it decreased significantly with the increment of exposure period.

Table 8. Effect of sodium fluoride (NaF) and/or M. Oleifera (MO) on super oxide dismutase (SOD) (U/g tissue) in tissue homogenates of $O$. niloticus gills, liver, kidney, and muscle.

\begin{tabular}{|c|c|c|c|c|c|}
\hline \multirow{2}{*}{ Groups } & \multicolumn{4}{|c|}{ Period of Exposure } & \multirow{2}{*}{$p$ value } \\
\hline & 2nd Week & 4th Week & 6th Week & 8th Week & \\
\hline \multicolumn{6}{|c|}{ Gills } \\
\hline CTR & $284.38+5.85^{\mathrm{B} \mathrm{b}}$ & $304.67+4.14^{\mathrm{A} \mathrm{a}}$ & $282.34+1.57^{\mathrm{B} \mathrm{b}}$ & $277.01+0.91^{\mathrm{B} \mathrm{b}}$ & 0.002 \\
\hline $\mathrm{NaF}$ & $276.19+3.53 \mathrm{~A} \mathrm{~b}$ & $269.62+2.65^{\mathrm{A}, \mathrm{B} b}$ & $264.49+2.15^{\mathrm{B}, \mathrm{C} C}$ & $258.99+0.91^{C c}$ & 0.023 \\
\hline $\mathrm{NaF}+\mathrm{MO}$ & $280.25+4.07 \mathrm{~A} \mathrm{~b}$ & $276.86+2.59 \mathrm{~A} \mathrm{~b}$ & $273.80+1.10^{\mathrm{A}, \mathrm{B} \mathrm{c}}$ & $265.37+1.54{ }^{B c}$ & 0.037 \\
\hline MO & $300.81+5.47 \mathrm{Ca}$ & $311.52+1.29$ В а & $317.08+2.72 \mathrm{~A}, \mathrm{~B}$ a & $323.94+1.73 \mathrm{~A} \mathrm{a}$ & 0.210 \\
\hline$p$ value & 0.036 & 0.021 & 0.013 & 0.001 & \\
\hline \multicolumn{6}{|c|}{ Liver } \\
\hline CTR & $390.00+2.54 \mathrm{~A} \mathrm{a,b}$ & $387.58+2.84 \mathrm{~A} \mathrm{~b}$ & $380.34+1.86^{\mathrm{A}, \mathrm{B} b}$ & $372.10+1.52^{\mathrm{B} \mathrm{b}}$ & 0.048 \\
\hline $\mathrm{NaF}$ & $373.70+2.49 \mathrm{Ac}$ & $348.85+2.86^{B ~ c}$ & $323.18+2.27^{C c}$ & $304.41+5.35^{\mathrm{Dc}}$ & 0.031 \\
\hline $\mathrm{NaF}+\mathrm{MO}$ & $381.56+4.37 \mathrm{~A} \mathrm{~b}, \mathrm{c}$ & $351.67+4.09$ B c & $330.39+1.47 \mathrm{Cc}$ & $323.07+2.53$ C c & 0.028 \\
\hline $\mathrm{MO}$ & $396.36+2.96^{\mathrm{Da}}$ & $411.38+0.45^{\mathrm{Ca}}$ & $423.79+1.96^{\text {В а }}$ & $437.34+3.13^{\mathrm{A} \mathrm{a}}$ & 0.011 \\
\hline$p$ value & 0.022 & 0.001 & 0.012 & 0.0009 & \\
\hline \multicolumn{6}{|c|}{ Kidney } \\
\hline CTR & $715.59+1.40 \mathrm{~A} \mathrm{a}$ & $711.53+4.93 \mathrm{~A} \mathrm{~b}$ & $714.92+6.52 \mathrm{~A} \mathrm{~b}$ & $707.14+2.26^{\mathrm{A} \mathrm{b}}$ & 0.656 \\
\hline $\mathrm{NaF}$ & $710.18+0.55$ А a & $693.25+2.25^{\text {B c }}$ & $681.60+1.23$ C c & $675.67+1.43^{C c}$ & 0.026 \\
\hline $\mathrm{NaF}+\mathrm{MO}$ & $711.48+1.47$ А a & $704.74+4.17^{\mathrm{A} \mathrm{b}}$ & $686.00+0.92 \mathrm{Bc}$ & $686.25+1.27^{B ~ c}$ & 0.033 \\
\hline $\mathrm{MO}$ & $719.35+0.49^{\text {В а }}$ & $722.18+0.77$ В а & $725.66+1.29 \mathrm{~A}, \mathrm{~B}$ a & $732.73+0.88 \mathrm{~A} \mathrm{a}$ & 0.048 \\
\hline$p$ value & 0.066 & 0.024 & 0.013 & 0.001 & \\
\hline \multicolumn{6}{|c|}{ Muscle } \\
\hline CTR & $176.66+2.52^{\mathrm{A}, \mathrm{B} a, \mathrm{~b}}$ & $178.53+1.99 \mathrm{~A} \mathrm{a}$ & $170.60+1.27^{\mathrm{B}, \mathrm{Cb}}$ & $168.76+3.44^{\mathrm{Cb}}$ & 0.049 \\
\hline $\mathrm{NaF}$ & $170.75+2.05^{\mathrm{A} \mathrm{b}}$ & $170.22+0.85^{\mathrm{Ab}}$ & $159.45+1.08^{B c}$ & $155.55+1.82^{\mathrm{Bc}}$ & 0.031 \\
\hline $\mathrm{NaF}+\mathrm{MO}$ & $171.01+0.80 \mathrm{~A} \mathrm{~b}$ & $167.35+0.33^{\mathrm{A}, \mathrm{B} b}$ & $164.29+0.64 \mathrm{~A}, \mathrm{~B} \mathrm{~b}, \mathrm{c}$ & $162.58+0.96^{\mathrm{B} b, c}$ & 0.044 \\
\hline $\mathrm{MO}$ & $182.36+1.29$ В а & $182.99+2.79$ В а & $187.99+2.48$ А,В a & $190.54+2.43 \mathrm{~A} \mathrm{a}$ & 0.026 \\
\hline$p$ value & 0.031 & 0.029 & 0.019 & 0.015 & \\
\hline
\end{tabular}

Different superscript small letters within the same column indicate significantly different mean values between different groups. Different superscript capital letters within the same row indicate significantly different mean values between different periods of exposure. CTR, control; $\mathrm{NaF}$, sodium fluoride (6.1 mg/L.); $\mathrm{NaF}+\mathrm{MO}$, sodium fluoride $(6.1 \mathrm{mg} / \mathrm{L})+$ Moringa oleifera extract ( $1 \%$ in ration); MO, M. oleifera extract ( $1 \%$ in ration).

\subsection{Effect of Sodium Fluoride and/or M. oleifera on Total Antioxidant Capacity (TAC) Activity in} Tissue Homogenate

As illustrated in Table 9, the levels of TAC in gills and liver tissues was significantly reduced in $\mathrm{NaF}$ and $\mathrm{NaF}+\mathrm{MO}$ groups at the 6th week of experiment and along the experimental period compared to control counterparts. Moreover, fish co-treated with MO showed significant elevation in TAC levels at the 8th week of experiment compared to their counterparts in the NaF-exposed group. Concerning the exposure period, a significant difference was detected at the 4th, 6th, and 8th weeks of experiment in NaF-exposed fish compared to the 2nd week.

Concerning the levels of TAC in kidney tissues, significant reduction was reported in $\mathrm{NaF}$ and $\mathrm{NaF}+\mathrm{MO}$ group fish at the 8th experiment compared to their control counterparts. Additionally, fish of the NaF $+\mathrm{MO}$ group showed a significant elevation in TAC levels at the 8th week of experiment compared to their counterparts in the NaF-exposed group. Concerning the exposure period, significant difference was detected at the 4th and 6th week of experiment in the NaF-exposed fish compared to their counterparts at the 2nd week. Levels of TAC in muscle tissues showed a significant decrease in the $\mathrm{NaF}$ and $\mathrm{NaF}+\mathrm{MO}$ groups at the 6th and 8th weeks of experiment, compared to their control counterparts. However, fish $\mathrm{NaF}+\mathrm{MO}$ group showed significant reduction in TAC at the 6th and 8 th weeks of the experiment compared to their counterparts in NaF-exposed group. Concerning the exposure period, a significant difference was detected in NaF-exposed fish at the 6th and 8th week of experiment compared to their counterparts at the 2 nd week. Fish receiving $\mathrm{MO}$ alone showed a significant upregulation in tissue TAC levels throughout the experiment in a time-dependent manner. 
Table 9. Effect of sodium fluoride (NaF) and/or M. Oleifera (MO) on total antioxidant capacity (TAC) $(\mathrm{U} / \mathrm{g}$ tissue) in tissue homogenates of $\mathrm{O}$. niloticus gills, liver, kidney, and muscle.

\begin{tabular}{|c|c|c|c|c|c|}
\hline \multirow{2}{*}{ Groups } & \multicolumn{4}{|c|}{ Period of Exposure } & \multirow{2}{*}{$p$ value } \\
\hline & 2nd Week & 4th Week & 6th Week & 8th Week & \\
\hline \multicolumn{6}{|c|}{ Gills } \\
\hline CTR & $1.45+0.005^{\mathrm{B} \mathrm{a}, \mathrm{b}}$ & $1.42+0.005^{C b}$ & $1.47+0.005^{\mathrm{B} \mathrm{b}}$ & $1.51+0.009 \mathrm{~A} \mathrm{~b}$ & 0.037 \\
\hline $\mathrm{NaF}$ & $1.42+0.008^{\mathrm{A} \mathrm{a}, \mathrm{b}}$ & $1.39+0.008^{\mathrm{Bb}}$ & $1.32+0.017^{C c}$ & $1.20+0.025^{\mathrm{Dd}}$ & 0.021 \\
\hline $\mathrm{NaF}+\mathrm{MO}$ & $1.39+0.008^{\mathrm{A} \mathrm{b}}$ & $1.40+0.001 \mathrm{~A} \mathrm{~b}$ & $1.37+0.008^{\mathrm{Ac}}$ & $1.38+0.014^{\mathrm{Ac}}$ & 0.072 \\
\hline $\mathrm{MO}$ & $1.46+0.043^{\mathrm{D} \mathrm{a}}$ & $1.51+0.023^{\mathrm{Ca}}$ & $1.58+0.024^{\mathrm{B} \mathrm{a}}$ & $1.67+0.020 \mathrm{~A} \mathrm{a}$ & 0.001 \\
\hline$p$ value & 0.023 & 0.019 & 0.008 & 0.009 & \\
\hline \multicolumn{6}{|c|}{ Liver } \\
\hline CTR & $4.73+0.011^{\mathrm{A}, \mathrm{B} a}$ & $4.71+0.048^{\mathrm{B} \mathrm{a}}$ & $4.73+0.024^{\mathrm{A}, \mathrm{B} b}$ & $4.82+0.023^{\mathrm{A} \mathrm{b}}$ & 0.046 \\
\hline $\mathrm{NaF}$ & $4.64+0.006^{\mathrm{A} \mathrm{a}}$ & $4.48+0.023^{\mathrm{B} \mathrm{b}}$ & $4.26+0.025 \mathrm{Cd}$ & $4.00+0.071^{\mathrm{D} \mathrm{d}}$ & 0.001 \\
\hline $\mathrm{NaF}+\mathrm{MO}$ & $4.67+0.008^{\mathrm{A} \mathrm{a}}$ & $4.55+0.041^{\mathrm{B} \mathrm{b}}$ & $4.57+0.018^{\mathrm{A}, \mathrm{B} c}$ & $4.62+0.020 \mathrm{~A}, \mathrm{~B} \mathrm{c}$ & 0.032 \\
\hline $\mathrm{MO}$ & $4.75+0.010 \mathrm{Ca}$ & $4.80+0.005 \mathrm{Ca}$ & $4.92+0.020^{\mathrm{B} \mathrm{a}}$ & $5.28+0.015 \mathrm{~A} \mathrm{a}$ & 0.026 \\
\hline$p$ value & 0.089 & 0.026 & 0.024 & 0.011 & \\
\hline \multicolumn{6}{|c|}{ Kidney } \\
\hline CTR & $3.88+0.017 \mathrm{~A} \mathrm{a}$ & $3.82+0.027 \mathrm{~A}, \mathrm{~B} b$ & $3.82+0.015^{\mathrm{B} \mathrm{b}}$ & $3.88+0.014^{\mathrm{A} \mathrm{b}}$ & 0.041 \\
\hline $\mathrm{NaF}$ & $3.85+0.009 \mathrm{~A} \mathrm{a}$ & $3.78+0.005^{\mathrm{B} \mathrm{b}}$ & $3.73+0.005^{B c}$ & $3.66+0.006^{C d}$ & 0.010 \\
\hline $\mathrm{NaF}+\mathrm{MO}$ & $3.86+0.020 \mathrm{~A} \mathrm{a}$ & $3.83+0.015^{\mathrm{A}, \mathrm{B} b}$ & $3.77+0.009^{B b, c}$ & $3.79+0.018^{\mathrm{Bc}}$ & 0.038 \\
\hline $\mathrm{MO}$ & $3.88+0.012 \mathrm{Ca}$ & $3.93+0.003^{\mathrm{Ca}}$ & $4.03+0.026^{\mathrm{Ba}}$ & $4.16+0.025^{\mathrm{A} \mathrm{a}}$ & 0.018 \\
\hline$p$ value & 0.073 & 0.044 & 0.028 & 0.038 & \\
\hline \multicolumn{6}{|c|}{ Muscle } \\
\hline CTR & $6.81+0.011^{\mathrm{B}, \mathrm{C} \mathrm{a}}$ & $6.78+0.012 \mathrm{Cb}$ & $6.85+0.015 \mathrm{~A}, \mathrm{~B} b$ & $6.87+0.023^{\mathrm{A} \mathrm{b}}$ & 0.036 \\
\hline $\mathrm{NaF}$ & $6.77+0.005^{\mathrm{A} a, b}$ & $6.72+0.003 \mathrm{Ac}$ & $6.65+0.006^{B d}$ & $6.59+0.005^{C d}$ & 0.033 \\
\hline $\mathrm{NaF}+\mathrm{MO}$ & $6.75+0.005^{\mathrm{A} \mathrm{a}, \mathrm{b}}$ & $6.76+0.010 \mathrm{~A} \mathrm{b,c}$ & $6.79+0.005 \mathrm{Ac}$ & $6.78+0.020 \mathrm{Ac}$ & 0.078 \\
\hline $\mathrm{MO}$ & $6.80+0.012 \mathrm{Ca}$ & $6.84+0.008^{\mathrm{Ca}}$ & $6.92+0.020^{\mathrm{B} \mathrm{a}}$ & $6.98+0.029$ А а & 0.011 \\
\hline$p$ value & 0.039 & 0.012 & 0.017 & 0.011 & \\
\hline
\end{tabular}

Different superscript small letters within the same column indicate significantly different mean values between different groups. Different superscript capital letters within the same row indicate significantly different mean values between different periods of exposure. CTR, control; $\mathrm{NaF}$, sodium fluoride (6.1 mg/L.); $\mathrm{NaF}+\mathrm{MO}$, sodium fluoride $(6.1 \mathrm{mg} / \mathrm{L})+$ Moringa oleifera extract ( $1 \%$ in ration); MO, M. oleifera extract ( $1 \%$ in ration).

3.9. Quantitative Analysis of mRNA Abundance of Glutathione S Transferase (GST) Genes in Liver Tissues of O. niloticus

As illustrated in Figure 3, the exposure of O. niloticus to $\mathrm{NaF}$ for eight weeks resulted in significant downregulation $(p<0.001)$ of GST gene expression, whereas the corresponding group of fish treated with $M$. oleifera were indistinguishable from controls. The administration of MO in combination with $\mathrm{NaF}$ resulted in a significant upregulation $(p<0.001)$ of GST gene expression compared to fish administrated $\mathrm{NaF}$ alone.

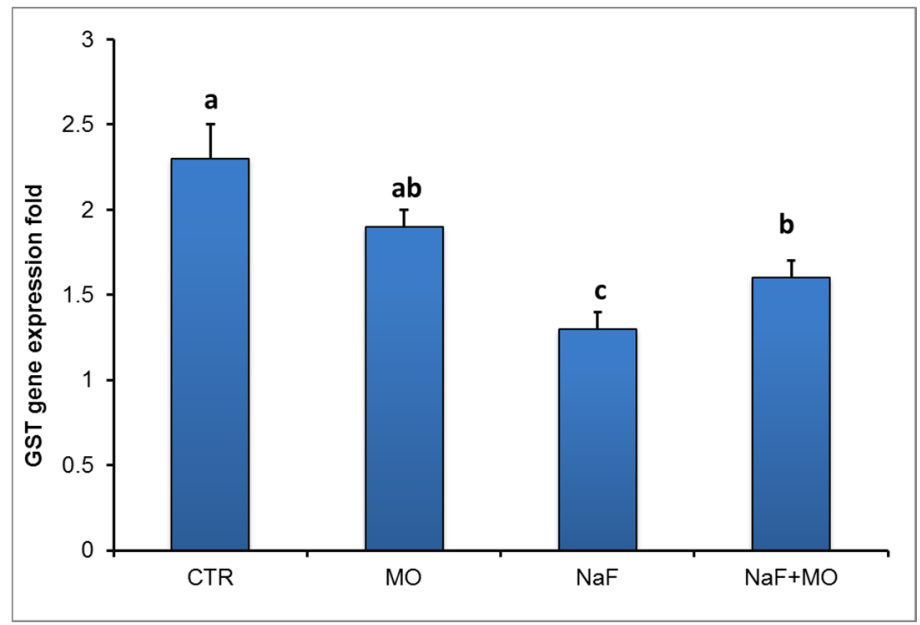

Figure 3. Effect of Moringa oleifera (MO) leaves extract on glutathione S transferase mRNA expression in O. niloticus. Six samples were analyzed to obtain an average concentration for each treatment. 


\section{Discussion}

Fluoride occurs normally in unpolluted waters at low concentrations (approximately $0.01-0.3 \mathrm{mg} / \mathrm{L}$ ). However, this level could increase more than 100 times due to the anthrogenic activities of humans [48]. The increased fluoride concentration usually leads to adverse impact on the cells of aquatic organisms due to various enzyme inhibitions [9]. These enzymatic responses are related to the increased production of reactive oxygen species (ROS) leading to oxidative stress $[49,50]$. In fish, oxidative stress can be defined as an imbalance between oxidants and antioxidant defences [51]. Excessive production of ROS is associated with severe reactions, such as damage of cellular proteins, lipids, and nucleic acid [52]. In addition, ROS can initiate the lipoperoxidation, which is a self-propagating process that leads to formation of peroxyl radical due to the reaction of ROS with the hydrogen atom from an intact lipid [52].

Although fish are able to accumulate fluoride through the food chain, few reports have investigated the adverse impacts of fluoride in fish [53]. For example, fluoride is able to delay the hatching of fertilized eggs, inhibit growth, and accumulates in the bone, gill, cartilage, and skin of fish $[5,48]$ and, importantly, it can promote oxidative damage by directly increasing the cellular concentration of ROS by altering the cellular antioxidant capacity in fish [54]. In the current study, the lethal concentration 50 (LC50) of sodium fluoride in O. niloticus was calculated as $61 \mathrm{mg} / \mathrm{L}$; therefore, a $1 / 10$ dose of LC50 $(6.1 \mathrm{mg} / \mathrm{L})$ was used to induce sub-chronic toxicity. A simple comparison with the previously calculated LC50 values in different species revealed that a $96 \mathrm{hr}$ LC50 was as low as $10.5 \mathrm{mg} / \mathrm{L}$ for the saltwater mysidacean Mysidopsis bahia [55]. However, the rainbow trout Oncorhynchus mykiss seems to be more sensitive to fluoride toxicity than other freshwater fish species. This difference in LC50 values may be attributed to the statement that the aquatic organisms living in soft waters may be more adversely affected by fluoride pollution than those living in hard or seawaters, where increasing water hardness leads to a reduction of fluoride bioavailability of fluoride ions due to the formation of innocuous complexes such as $\mathrm{CaF} 2, \mathrm{Ca} 5$ (PO4)3F, and MgF2 [56].

The findings of the sub-chronic toxicity in this study indicate the adverse oxidative effect of sodium fluoride in the gills, liver, kidney, and muscle tissues. Fluoride has a small ionic radius and high biological activity; therefore, it can penetrate easily into the cells and exerting its adverse effects on various tissues [57]. In addition, some metals, including fluoride, are known for its powerful oxidant effect; they can deplete the major antioxidants in the cell, particularly thiol-containing antioxidants enzymes [49]. Interestingly, the sodium fluoride-related oxidative stress was defined in a time-dependent manner. This time-related progression in the described oxidative stress may be attributed to the exhaustion of the antioxidant system via continuous exposure to sodium fluoride.

Lipid peroxidation is usually used as an indicator of oxidative stress in different tissues [58]. Malondialdehyde (MDA) represents the indicative end product of lipid peroxidation process in various tissues or biological fluids [59]. In the current study, a significant increase in the MDA level was observed in the gills, liver, kidney, and muscle tissues after exposure to fluoride. This increase in MDA levels represented an indicator for enhanced oxidative stress [60]. Induction of lipid peroxidation (LPO) and its related disturbance in the cell membranes' integrity and inhibition of the membrane-bound enzymes was already reported previously [61].

In the current work, fish exposed to sodium fluoride $(\mathrm{NaF})$ for eight weeks developed a significant reduction in the level of GSH and activity of SOD, CAT, and TAC in tissue homogenates of the liver, gills, kidney, and muscle. GSH is a main non-enzymatic endogenous antioxidant that prevents ROS and peroxide-induced cellular damage [62]. In addition, GSH works as a direct scavenger for free radicals and as a substrate for GPx and GST. Therefore, the reduction of GSH reported in this study may be attributed to its direct conjugation with the electrophiles generated due to sodium fluoride exposure. Similar reduction in the GSH level was previously reported in freshwater fish after exposure to other organophosphate methyl parathions [63].

SOD is an important antioxidant enzyme, it is considered as the first enzymatic defense against the superoxide anion. SOD is responsible for catalyzing the ROS binding with water to generate $\mathrm{H}_{2} \mathrm{O}_{2}$. 
Following that, the breakdown of $\mathrm{H}_{2} \mathrm{O}_{2}$ to water and oxygen is occurred via CAT to protect cells from the damaging effect of $\mathrm{H}_{2} \mathrm{O}_{2}$ and the hydroxyl radicals. These events may introduce an accepted explanation for the reduction in SOD and CAT level reported in the present study after exposure to fluoride. In addition, the observed reduction in SOD activity in fluoride-exposed fish may also be attributed to the direct competitive inhibition of enzyme activity by fluoride [64]. A similar finding was reported by many investigators [65,66]. In similar context, GPx is responsible for catalyzing the hydroperoxide reaction with reduced GSH and the resultant formation of glutathione disulfide. In the current work, exposure to sodium fluoride led to the reduction of the GPx activity in different tissues of sodium fluoride-exposed fish as compared to the control group. This finding may be attributed to the decreased activity of GSH which acts as a substrate for GPx. A similar finding was previously reported by Sharma et al. [67]. In addition, this reduction in $\mathrm{GP}_{X}$ activity could be attributed to the direct effects of metal ions on the active site of enzyme molecules. Waheed et al. [68] also indicated significant alterations in GPx activity together with SOD and CAT activities in the tissues of fish Oreochromis niloticus after $\mathrm{Hg}$ exposures.

GSTs are a family of phase II detoxifying enzymes that are responsible for the conjugation of GSH to several electrophilic compounds [69]. In fish, GSTs play a major role in the antioxidant function and detoxification of various xenobiotics including fluoride. Several studies have been already reported that fluroacetamide reduced GST activity in various tissues due to oxidative stress [70,71]. This reduction of GST activity is directly related to increased levels of lipid peroxidation, where it plays a crucial role in eliminating MDA, the end-products of oxidative damage. Interestingly, the molecular expression of GST may be considered as a biomarker for xenobiotics exposure [72-74]. Many toxicologists expect that the highest level of GST expression may occur in the liver where metabolism mostly occurs [75]. In this study, the mRNA expression of GST in the liver of NaF-exposed fish showed a significant reduction compared to control fish. This reduction in GST may be related to the significant reduction of GSH, which is the substrate for GPx that provides a mechanism for GST involvement in the conjugation and elimination of fluoride [76]. In addition, it is well known that the GST enzyme catalyzes the reaction via the thiol (-SH) group of glutathione (GSH) leading to the neutralization of the xenobiotic and making it more water soluble [77]. However, supplementation of MO to NaF-exposed fish led to a significant elevation of GST mRNA expression in the liver. This elevation in GST activity might be attributed to the decline of free radical production by MO supplementation which, in turn, increases in the antioxidant system.

Co-administration of Moringa oleifera (MO) leaf extract led to a significant improvement of the antioxidative status of treated fish. The leaves of $\mathrm{MO}$ are rich in minerals (such as iron and calcium), vitamins (such as Vit. A, B and C), and proteins (such as methionine, cysteine, and essential sulfur amino acid) [78]. All parts of $\mathrm{MO}$ can act as good sources of natural antioxidants due to the presence of various types of antioxidant compounds, such as ascorbic acid, flavonoids, phenolics, and carotenoids [78]. In our study, the gas chromatography-mass spectrometry analysis of MO leaves revealed that they contain many antioxidant agents, such as eugenol $(45.23 \%)$, caryophyllene $(11.35 \%)$, hexadecanoic acid $(7.23 \%)$, phenol $(6.14 \%)$, octadecenoc acid $(3.29 \%)$, heptadecyne $(3.18 \%)$, cyclopropanoctonic $(4.17 \%)$, heptatriacotanole $(1.26 \%)$, and quercetin $(0.89 \%)$. These natural antioxidant substances can illustrate the antioxidant property of $\mathrm{MO}$ against induced oxidative stress [79]. Moringa oleifera has been reported to exhibit efficient antioxidant and free-radical scavenging properties via lowering LPO levels in various tissues [32]. In this study, MO brought MDA levels to a normal level, and replenished the decreased level of GSH, SOD, and CAT, possibly due to its capability of scavenging the free radical generated after fluoride exposure. This replenishing of GSH may be responsible for the regaining of GPx and GST activity. The antioxidant capacity of MO has already been reported in some investigations; Onah et al., [32] concluded that supplementation of MO extracts is associated with a significant improvement in the levels of both liver and kidney GST, SOD, and CAT during lead acetate intoxication in fish [33]. Similarly, Uma et al. [34] and Fakurazi et al. [35] showed that MO leaves protected against acetaminophen-induced liver damage by decreasing liver enzymes and hepatic 
lipid peroxidation as well as increasing antioxidant enzyme levels. Similarly, MO improved MDA, SOD, GST, and CAT during lead acetate administration in fish [80]. The chemically-modified MO leaf powder was previously used by Reddy et al. [81] for optimization of $\mathrm{Cd}, \mathrm{Cu}$, and Ni biosorption. Removing of $\mathrm{Cd}$ from waste water was achieved using fresh leaves as biosorbents.

\section{Conclusion and Limitation}

On the basis of the present findings, it can be concluded that increased sodium fluoride content in water causes adverse oxidative stress on various fish tissues. The changes of tissue biomarkers as antioxidant enzymes were the physiological responses of $O$. niloticus to the stress of sodium fluoride exposure. Moringa oleifera $1 \%(w / w)$ ration is a promising plant-based antioxidant that may be grown to produce more natural products and materials against heavy metals toxicity and oxidation processes induced by $\mathrm{NaF}$ in various tissues of Nile tilapia. Estimation of growth data and the possibility of their modulation by oxidative stress induced by sodium fluoride and/or co-treatment with Moringa oleifera, as well as the measurement of water quality parameters, are important limitations of this study which must be considered in further studies.

Author Contributions: Data curation: K.M.S., S.N.M. and A.A.A.; formal analysis: R.H.K.; funding acquisition: J.S.A. and S.N.M.; investigation: N.F.A.; methodology: K.M.S. and M.K.S.; resources: M.K.S. and J.S.A.; software: R.H.K. and A.A.A.; supervision: A.F.K.; writing-original draft: N.F.A.; writing-review and editing: A.F.K. All authors have read and agreed to the published version of the manuscript.

Funding: This study was supported by the Research Supporting Project (RSP-2019/149), King Saud University, Riyadh, Saudi Arabia.

Acknowledgments: The authors acknowledge King Saud University, Riyadh, Saudi Arabia, for funding this work through Researchers Supporting Project (RSP-2019/149).

Conflicts of Interest: The authors declare no conflict of interest.

\section{Abbreviations}

$\begin{array}{ll}\text { NaF } & \text { Sodium fluoride } \\ \text { O. niloticus } & \text { Oreochromis niloticus } \\ \text { MO } & \text { Moringa oleifera } \\ \text { LC50 } & \text { Lethal concentration } 50 \\ \text { MDA } & \text { Malondialdehyde } \\ \text { CAT } & \text { Catalase } \\ \text { SOD } & \text { Super oxide dismutase } \\ \text { GPx } & \text { Glutathione peroxidase } \\ \text { GST } & \text { Glutathione S transferase } \\ \text { GSH } & \text { Glutathione reduced } \\ \text { TAC } & \text { Total antioxidant capacity }\end{array}$

\section{References}

1. Zuo, H.; Chen, L.; Kong, M.; Qiu, L.; Lü, P.; Wu, P.; Yang, Y.; Chen, K. Toxic effects of fluoride on organisms. Life Sci. 2018, 198, 18-24. [CrossRef] [PubMed]

2. Datta, D.K.; Gupta, L.P.; Subramanian, V. Dissolved fluoride in the lower Ganges-Brahmaputra-Meghna River system in the Bengal Basin, Bangladesh. Environ. Geol. 2000, 39, 1163-1168. [CrossRef]

3. Osterman, J.W. Evaluating the Impact of Municipal Water Fluoridation on the Aquatic Environment. Am. J. Public Health 1990, 80, 1230-1235. [CrossRef] [PubMed]

4. Camargo, J.A.; Tarazona, J.V. Short-term toxicity of fluoride ion (F) in soft water to rainbow trout and brown trout. Chemosphere 1991, 22, 605-611. [CrossRef]

5. Pillai, K.S.; Mane, U.H. The effect of fluoride on fertilized eggs of a freshwater fish, Catla catla (Hamilton). Toxicol. Lett. 1984, 22, 139-144. [CrossRef]

6. Tripathi, M.; Tripathi, A.; Gopal, K. Impact of fluoride on pigmentation of a freshwater fish Channa punctatus. J. Appl. Biosci. 2005, 31, 35-38. 
7. Shi, X.; Zhuang, P.; Zhang, L.; Feng, G.; Chen, L.; Liu, J.; Wang, R. Growth inhibition of Siberian Sturgeon (II) from dietry and waterborne fluoride. Res. Rep. Fluoride 2009, 42, 137-141.

8. Khan, Z.N.; Sabino, I.T.; De Souza Melo, C.G.; Martini, T.; Da Silva Pereira, H.A.B.; Buzalaf, M.A.R. Liver proteome of mice with distinct genetic susceptibilities to fluorosis treated with different concentrations of $\mathrm{F}$ in the drinking water. Biol. Trace Element Res. 2018, 187, 107-119. [CrossRef]

9. Barbier, O.; Arreola-Mendoza, L.; Del Razo, L.M. Molecular mechanisms of fluoride toxicity. Chem. Biol. Interact. 2010, 188, 319-333. [CrossRef]

10. Dec, K.; Lukomska, A.; Maciejewska, D.; Jakubczyk, K.; Baranowska-Bosiacka, I.; Chlubek, D.; Wasik, A.; Gutowska, I. The influence of fluorine on the disturbances of homeostasis in the central nervous system. Biol. Trace Element Res. 2016, 177, 224-234. [CrossRef]

11. Kuang, P.; Deng, H.; Cui, H.; Chen, L.; Fang, J.; Zuo, Z.; Deng, J.; Wang, X.; Zhao, L. Sodium fluoride (NaF) causes toxic effects on splenic development in mice. Oncotarget 2016, 8, 4703-4717. [CrossRef] [PubMed]

12. Saumya, S.M.; Basha, M.P. Fluoride exposure aggravates the testicular damage and sperm quality in diabetic mice: Protective role of ginseng and banaba. Biol. Trace Element Res. 2016, 177, 331-344.

13. Pereira, H.A.L.; Leite, A.; Charone, S.; Lobo, J.G.V.M.; Cestari, T.M.; Peres-Buzalaf, C.; Buzalaf, M.A.R. Proteomic analysis of liver in rats chronically exposed to fluoride. PLoS ONE 2013, 8, e75343. [CrossRef]

14. Pereira, H.A.; Dionizio, A.S.; Fernandes, M.S.; Araujo, T.T.; Cestari, T.M.; Buzalaf, C.P.; Iano, F.G.; Buzalaf, M.A.R. Fluoride intensifies hypercaloric diet-induced ER oxidative stress and alters lipid metabolism. PLoS ONE 2016, 11. [CrossRef] [PubMed]

15. Chen, J.J.; Cao, J.L.; Wang, J.D.; Jia, R.H.; Xue, W.J.; Li, Y.D.; Luo, Y.J.; Xie, L. Effects of fluoride on growth, body composition, and serum biochemical profile in a freshwater teleost, Cyprinus Carpio. Environ. Toxicol. Chem. 2013, 32, 2315-2321. [CrossRef]

16. Chowdhury, C.; Khijmatgar, S.; Kumari, D.P.; Chowdhury, A.; Grootveld, M.; Hegde, C.; Lynch, E. Fluoride in fish flesh, fish bone and regular diet in south-coastal area of Karnataka state of India. Indian J. Dental Res. 2018, 29, 414-417. [CrossRef]

17. Chen, J.J.; Cao, J.L.; Wang, J.D.; Jia, R.H.; Xue, W.J.; Xie, L.T. Fluoride-induced apoptosis and expressions of caspase proteins in the kidney of Carp (Cyprinus carpio). Environ. Toxicol. 2014, 3, 24-37. [CrossRef]

18. Izquierdo-Vega, J.A.; Sanchez-Gutierrez, M.; Del Razo, L.M. Decreased in vitro fertility in male rats exposed to fluoride-induced oxidative stress damage and mitochondrial transmembrane potential loss. Toxicol. Appl. Pharmacol. 2008, 230, 352-357. [CrossRef]

19. Ribeiro, D.A.; Yujra, V.Q.; Da Silva, V.H.P.; Claudio, S.R.; Estadella, D.; Viana, M.; Oshima, C.T.F. Putative mechanisms of genotoxicity induced by fluoride: A comprehensive review. Environ. Sci. Poll. Res. Inter. 2017, 24, 15254-15259. [CrossRef]

20. Arif, M.; Hayat, Z.; Abd El-Hack, M.E.; Saeed, M.; Imran, H.M.; Alowaimer, A.N.; Saadeldin, I.M.; Taha, A.E.; Swelum, A.A. Impacts of supplementing broiler diets with a powder mixture of black cumin, Moringa and chicory seeds. S. Afr. J. Anim. Sci. 2019, 49. [CrossRef]

21. Suphachai, C. Antioxidant and anticancer activities of Moringa oleifera leaves. J. Medic. Plant Res. 2014, 8, 318-325. [CrossRef]

22. Kou, X.; Li, B.; Olayanju, J.; Drake, J.; Chen, N. Nutraceutical or pharmacological potential of Moringa oleifera Lam. Nutrients 2018, 10, 343. [CrossRef] [PubMed]

23. Minaiyan, M.; Asghari, G.; Taheri, D.; Saeidi, M.; Nasr-Esfahani, S. Anti-inflammatory effect of Moringa oleifera Lam. Seeds on acetic acid-induced acute colitis in rats. Avicenna J. Phytomed. 2014, 4, 127-136. [PubMed]

24. Misra, A.; Srivastava, S.; Srivastava, M. Evaluation of antidiarrheal potential of Moringa oleifera (Lam.) leaves. J. Pharmacogn. Phytochem. 2014, 2, 43-46.

25. Kalkunte, S.; Swamy, N.; Dizon, D.S.; Brard, L. Benzyl isothiocyanate (BITC) induces apoptosis in ovarian cancer cells in vitro. J. Exp. Therap. Oncol. 2006, 5, 287-300.

26. Satyan, K.S.; Swamy, N.; Dizon, D.S.; Singh, R.; Granai, C.O.; Brard, L. Phenethyl isothiocyanate (PEITC) inhibits growth of ovarian cancer cells by inducing apoptosis: Role of caspase and MAPK activation. Gynecol. Oncol. 2006, 103, 261-270. [CrossRef]

27. Elgamily, H.; Moussa, A.; Elboraey, A.; El-Sayed, H.; AlMoghazy, M.; Abdalla, A. Microbiological assessment of Moringa oleifera extracts and its incorporation in novel dental remedies against some oral pathogens. Open Access Macedonian J. Med. Sci. 2016, 4, 585-590. [CrossRef] 
28. Richter, N.; Siddhuraju, B.; Becker, K. Evaluation of nutritional quality of Moringa (Moringa oleifera Lam.) leaves as an alternative protein source for Nile tilapia (Oreochromis niloticus L.). Aquaculture 2003, 217, 599-611. [CrossRef]

29. Garcia-Santos, S.; Fontainhas-Fernandes, A.; Wilson, J.M. Cadmium tolerance in the Nile tilapia (Oreochromis niloticus) following acute exposure: Assessment of some ionoregulatory parameters. Environ. Toxicol. 2006, 21, 33-46. [CrossRef]

30. Abdel Latif, H.M.; Khafaga, A.F. Natural co-infection of cultured Nile tilapia Oreochromis niloticus with Aeromonas hydrophila and Gyrodactylus cichlidarum experiencing high mortality during summer. Aquacul Res 2020. [CrossRef]

31. Sayed, A.E.; Hamed, H.S. Induction of apoptosis and DNA damage by 4-nonylphenol in African catfish (Clarias gariepinus) and the antioxidant role of Cydonia oblonga. Ecotoxicol. Environ. Saf. 2017, 139, 97-101. [CrossRef] [PubMed]

32. Onah, C.E.; Meludu, S.C.; Dioka, C.E.; Onuegbu, A.J.; Onah, C.F.; Ajaghaku, D.L.; Nnodim, J.K.; Obi, E. Amelioratory Effect of Methanolic Leaf Extract of Moringa oleifera on Some Liver and Kidney Function and Oxidative Stress Markers in Lead-intoxicated. EJMP 2016, 12, 1-12. [CrossRef]

33. Ashour, E.A.; El-Kholy, M.S.; Alagawany, M.; Abd El-Hack, M.E.; Mohamed, L.A.; Taha, A.E.; El Sheikh, A.I.; Laudadio, F.; Tufarelli, F. Effect of Dietary Supplementation with Moringa oleifera Leaves and/or Seeds Powder on Production, Egg Characteristics, Hatchability and Blood Chemistry of Laying Japanese Quails. Sustainability 2020, 12, 2463. [CrossRef]

34. Uma, N.; Fakurazi, S.; Hairuszah, I. Moringa oleifera enhances liver antioxidant status via elevation of the antioxidant enzyme activity and counteracts paracetamol-induced hepatotoxicity. Malays J. Nutr. 2010, 16, 293-307. [PubMed]

35. Fakurazi, S.; Sharifudin, S.A.; Arulselvan, P. Moringa oleifera hydroethanolic extracts effectively alleviate acetaminophen induced hepatotoxicity in experimental fish through their antioxidant nature. Molecules 2012, 17, 8334-8350. [CrossRef] [PubMed]

36. Hamed, H.S.; Abdel-Tawwab, M. Ameliorative effect of propolis supplementation on alleviating bisphenol-A toxicity: Growth performance, biochemical variables, and oxidative stress biomarkers of Nile tilapia, Oreochromis niloticus (L.) fingerlings. Comp. Biochem. Physiol. C Toxicol. Pharmacol. 2017, 202, 63-69. [CrossRef]

37. El-Sabbagh, N.M.; Shakweer, M.S.; Ghetas, H.A. Positive Pharmacological Effects of Methanolic Leaf Extract of Moringa oleifera on Some Liver and Kidney Functions and Oxidative Stress Markers in Sea Bream Sparus auratus L. Exposed to Sodium Fluoride toxicity. AJVS 2019, 63, 142-155. [CrossRef]

38. Okechukwu, U.P.C.; Okwesili, N.F.C.; Parker, J.E.; Christian, O.E.; Emmanuel, O.C.; Aburbakar, B. Ameliorative effects of ethanol leaf extract of Moringa oleifera on the liver and kidney markers of malaria infected mice. Int. J. Life Sci. Biotechnol. Pharma. Res. 2013, 2, 44-46.

39. Eurell, T.E.; Lewis, S.D.H.; Grumbles, L.C. Comparison of selected diagnostic tests for detection of motile Aeromonas Septicemia in fish. Am. J. Vol. Res. 1978, 39, 1384-1386.

40. Behrens, A.S.; Karber, L. Determination of LC50. Arch. Exp. Path. Pharm. 1953, $28,177$.

41. Singh, R.; Khatri, P.; Srivastava, N.; Jain, S.; Brahmachari, V.; Mukhopadhyay, A.; Mazumder, S. Fluoride exposure abates pro-inflammatory response and induces in vivo apoptosis rendering zebrafish (Danio rerio) susceptible to bacterial infections. Fish Shellfish Immunol. 2017, 63, 314-321. [CrossRef] [PubMed]

42. Ohkawa, H.; Ohishi, N.; Yagi, K. Assay for lipid peroxides in animal tissues by thiobarbituric acid reaction. Anal. Biochem. 1979, 95, 351-358. [CrossRef]

43. Nishikimi, M.; Appaji, N.; Yagi, K. The occurrence of superoxide anion in the reaction of reduced phenazine methosulfate and molecular oxygen. Biochem. Biophys. Res. Commun. 1972, 46, 849-854. [CrossRef]

44. Aebi, H. Catalase in vitro. Methods Enzymol. 1984, 105, 121-126. [PubMed]

45. Paglia, D.E.; Valentine, W.N. Studies on the quantitative and qualitative characterization of erythrocyte glutathione peroxidase. J. Lab. Clin. Med. 1967, 70, 158-169. [PubMed]

46. Beutler, E.; Duron, O.; Kelly, B.M. Improved method for the determination of blood glutathione. J. Lab. Clin. Med. 1963, 61, 882-888.

47. Yuan, J.S.; Reed, A.; Chen, F.; Stewart, C.N. Statistical analysis of real-time PCR data. BMC Bioinform. 2006, 7, 85. [CrossRef]

48. Camargo, J.A. Fluoride toxicity to aquatic organisms: A review. Chemosphere 2003, 50, 251-264. [CrossRef] 
49. Pinto, E.; Sigaud-Kutner, T.C.S.; Leitao, M.A.S.; Okamoto, O.K.; Morse, D.; Colepicolo, P. Heavy metal-induced oxidative stress in algae. J. Phycol. 2003, 39, 1008-1018. [CrossRef]

50. Martínez-Álvarez, R.M.; Morales, A.E.; Sanz, A. Antioxidant defenses in fish: Biotic and abiotic factors. Rev. Fish Biol. Fish. 2005, 15, 75-88. [CrossRef]

51. Almeida, J.A.; Barreto, R.E.; Novelli, E.L.B.; Castro, F.J.; Moron, S.E. Oxidative stress biomarkers and aggressive behavior in fish exposed to aquatic cadmium contamination. Neotrop Ichthyol. 2009, 7, 103-108. [CrossRef]

52. El Okle, O.S.; El Euony, O.I.; Khafaga, A.F.; Lebda, M.A. Thiamethoxam induced hepatotoxicity and pro-carcinogenicity in rabbits via motivation of oxidative stress, inflammation, and anti-apoptotic pathway. Environ Sci Poll Res 2018, 25, 4678-4689. [CrossRef] [PubMed]

53. Yoshitomi, B.; Aoki, M.; Oshima, S.; Hata, K. Evaluation of krill (Euphausia superba) meal as a partial replacement for fish meal in rainbow trout (Oncorhynchus mykiss) diets. Aquaculture 2007, 261, 440-446. [CrossRef]

54. Baysoy, E.; Atli, G.; Gürler, C.Ö.; Dogan, Z.; Eroglu, A.; Kocalar, K.; Canli, M. The effects of increased freshwater salinity in the biodisponibility of metals $(\mathrm{Cr}, \mathrm{Pb})$ and effects on antioxidant systems of Oreochromis niloticus. Ecotoxicol. Environ. Saf. 2012, 84, 249-253. [CrossRef] [PubMed]

55. LeBlanc, G.A. Interspecies relationships in acute toxicity of chemicals to aquatic organisms. Environ. Toxicol. Chem. 1984, 3, 47-60. [CrossRef]

56. Smith, L.R.; Holsen, T.M.; Ibay, N.C.; Block, R.M.; Leon, A.B. Studies on the acute toxicity of fluoride ion to stickleback, fathead minnow and rainbow trout. Chemosphere 1985, 14, 1383-1389. [CrossRef]

57. Devi, A.J.; Piska, R.S. Effect of fluoride on tissue proteins of fresh water cat fish Clarias batrachus (Lin.). J. Aquat. Biol. 2006, 21, 184-187.

58. Khafaga, A.F.; Bayad, A.E. Ginkgo biloba extract attenuates hematological disorders, oxidative stress and nephrotoxicity induced by single or repeated injection cycles of cisplatin in rats: Physiological and Pathological Studies. Asian J. Anim. Sci. 2016, 10, 235-246.

59. Khafaga, A.F. Exogenous phosphatidylcholine supplementation retrieve aluminum-induced toxicity in male albino rats. Environ Sci Poll Res 2017, 24, 15589-15598. [CrossRef]

60. Buyukokuroglu, M.E.; Taysi, S.; Polat, F.; Gocer, F. Mechanism of the beneficial effects of dantrolene sodium on ethanol-induced acute gastric mucosal injury in rats. Pharmacol. Res. 2002, 45, 421-425. [CrossRef]

61. Aladaileh, S.H.; Khafaga, A.F.; El-Hack, M.E.A.; Al-Gabri, N.A.; Abukhalil, M.H.; Alfwuaires, M.A.; Bin-Jumahg, M.; Alkahtani, M.; Abdel-Daim, M.; Aleya, L.; et al. Spirulina platensis ameliorates the sub chronic toxicities of lead in rabbits via anti-oxidative, anti-inflammatory, and immune stimulatory properties. Sci. Total Environ. 2020, 701, 134879. [CrossRef] [PubMed]

62. Pompella, A.; Visvikis, A.; Paolicchi, A.; De Tata, V.; Casini, A.F. The changing faces of glutathione, a cellular protagonist. Biochem. Pharmacol. 2003, 66, 1499-1503. [CrossRef]

63. Monteiro, D.A.; De Almeida, J.A.; Rantin, F.T.; Kalinin, A.L. Oxidative stress biomarkers in the freshwater characid fish, Brycon cephalus, exposed to organophosphorus insecticide Folisuper 600 (methyl parathion). Comp. Biochem. Physiol. C Toxicol. Pharmacol. 2006, 143, 141-149. [CrossRef] [PubMed]

64. Zhan, X.A.; Wang, M.; Xu, Z.R.; Li, W.F.; Li, J.X. Effects of fluoride on hepatic antioxidant system and transcription of $\mathrm{Cu} / \mathrm{Zn}$ SOD gene in young pigs. J. Trace Elem. Med. Biol. 2006, 20, 83. [CrossRef]

65. Atif, F.; Parvez, S.; Pandey, S.; Ali, M.; Kaur, M.; Rehman, H.; Khan, H.A.; Raisuddin, S. Modulatory effect of cadmium exposure on deltamethrin-induced oxidative stress in Channa punctataBloch. Arch. Environ. Contam. Toxicol. 2005, 49, 371-377. [CrossRef]

66. Bouraoui, Z.; Banni, M.; Ghedira, J.; Clerandeau, C.; Guerbej, H.; Narbonne, J.F.; Boussetta, H. Acute effects of cadmium on liver Phase I and Phase II enzymes and metallothionein accumulation on sea bream Sparus aurata. Fish Physiol. Biochem. 2008, 34, 201-207. [CrossRef]

67. Sharma, P.; Singh, R.; Jan, M. Dose-dependent effect of deltamethrin in testes, liver, and kidney of wistar rats. Toxicol. Int. 2014, 21, 131-139.

68. Waheed, R.; El Asely, A.M.; Bakery, H.; El-Shawarby, R.; Abuo-Salem, M.; Abdel-Aleem, N.; Malhat, F.; Khafaga, A.F.; Abdeen, A. Thermal stress accelerates mercury chloride toxicity in Oreochromis niloticus via up-regulation of mercury bioaccumulation and HSP70 mRNA expression. Sci. Total Environ. 2020, 718, 137326. [CrossRef] 
69. Talalay, P. Chemical Protection Against Cancer by Induction of Electrophile Detoxification (Phase II) Enzymes. Cellular and Molecular Targets for Chemoprevention; CRC Press: Boca Raton, FL, USA, 1992; pp. 193-205.

70. Patel, D.; Chinoy, N.J. Ameliorative role of amino acid on fluoride induced alteration in mice (part 2): Ovarion and uterine nucleic acid metabolism. Fluoride 1998, 31, 143-148.

71. Dierickx, P.J.; De Beer, J.O. Interaction of fluoroacetamide with rat liver glutathione S- transferases: Evidence for detoxification roles by defluorination. Fluoride 1983, 16, 145-151.

72. Pandey, S.; Parvez, S.; Sayeed, I.; Haque, R.; Bin-Hafeez, B.; Raisuddin, S. Biomarkers of oxidative stress: A comparative study of river Yamuna fish, Wallago attu (Bl. \& Schn.). Sci. Total Environ. 2003, 309, 105-115. [PubMed]

73. Sayeed, I.; Parvez, S.; Pandey, S.; Bin-Hafeez, B.; Haque, R.; Raisuddin, S. Oxidative stress biomarkers of exposure to deltamethrin in freshwater fish, Channa punctatus Bloch. Ecotoxicol. Environ. Saf. 2003, 56, 295-301. [CrossRef]

74. Sarkar, A.; Ray, D.; Shrivastava, A.N.; Sarker, S. Molecular biomarkers: Their significance and application in marine pollution monitoring. Ecotoxicology 2006, 15, 333-340. [CrossRef] [PubMed]

75. Li, G.; Xie, P.; Li, H.; Chen, J.; Hao, L.; Xiong, Q. Quantitative profiling of mRNA expression of glutathione S-transferase superfamily genes in various tissues of bighead carp (Aristichthys nobilis). J. Biochem. Mol. Toxicol. 2010, 24, 250-259. [CrossRef] [PubMed]

76. García-Alfonso, C.; Martínez-Galisteo, E.; Llobell, A.; Bárcena, J.A.; López-Barea, J. Horse- Liver glutathione reductase: Purif ication and characterization. Int. J. Biochem. 1993, 25, 61-68. [CrossRef]

77. Ervello, I.; Lafuente, A.; Giralt, M.; Mallol, J. Modifications of glutathione S-transferase (GST) activity in the last period of pregnancy in rats treated with benzo (a) pyrene (BP). Placenta 1992, 13, 273-280. [CrossRef]

78. Foidl, N.; Makkar, H.P.S.; Becker, K. The potential of Moringa oleifera for agricultural and industrial uses. In The Miracle Tree: The Multiple Attribute of Moringa; Fuglie, L.J., Ed.; CWS: Dakar, Senegal, 2001; pp. 45-76.

79. Compaoré, W.R.; Nikièma, P.A.; Bassolé, H.I.N.; Savadogo, A.; Mouecoucou, J. Chemical composition and antioxidative properties of seeds of Moringa oleifera and pulps of Parkia biglobosa and Adansonia digitata commonly used in food fortification in Burkina Faso. Curr. Res. J. Biol. Sci. 2011, 3, 64-72.

80. Reddy, D.H.K.; Seshaiah, K.; Reddy, A.V.R.; Lee, S.M. Optimization of Cd (II), Cu (II) and Ni (II) biosorption by chemically Modified Moringa oleifera leaves powder. Carbohydr. Polym. 2012, 88, 1077-1086. [CrossRef]

81. Ali, E.N. Moringa oleifera Leaves Possible uses as environmentally Friendly Material: A Review. Int. J. Chem. Environ. Biol. Sci. 2014, 2, 23-36. 